Board of Governors of the Federal Reserve System

International Finance Discussion Papers

Number 1312

March 2021

\title{
The Dollar and Corporate Borrowing Costs
}

Ralf R. Meisenzahl, Friederike Niepmann, and Tim Schmidt-Eisenlohr

Please cite this paper as:
Meisenzahl, Ralf R., Friederike Niepmann, and Tim Schmidt-Eisenlohr (2021).
"The Dollar and Corporate Borrowing Costs," International Finance Discussion Pa-
pers 1312. Washington: Board of Governors of the Federal Reserve System,
https://doi.org/10.17016/IFDP.2021.1312.

NOTE: International Finance Discussion Papers (IFDPs) are preliminary materials circulated to stimulate discussion and critical comment. The analysis and conclusions set forth are those of the authors and do not indicate concurrence by other members of the research staff or the Board of Governors. References in publications to the International Finance Discussion Papers Series (other than acknowledgement) should be cleared with the author(s) to protect the tentative character of these papers. Recent IFDPs are available on the Web at www.federalreserve.gov/pubs/ifdp/. This paper can be downloaded without charge from the Social Science Research Network electronic library at www.ssrn.com. 


\title{
The Dollar and Corporate Borrowing Costs*
}

\author{
Ralf R. Meisenzahl \\ Friederike Niepmann \\ Chicago FED Federal Reserve Board \\ Tim Schmidt-Eisenlohr \\ Federal Reserve Board
}

\begin{abstract}
We show that U.S. dollar movements affect syndicated loan terms for U.S. borrowers, even for those without trade exposure. We identify the effect of dollar movements using spread and loan amount adjustments during the syndication process. Using this high-frequency, within loan variation, we find that a one standard deviation increase in the dollar index increases spreads by up to 15 basis points and reduces loan amounts and underpricing by up to 2 percent and 7 basis points, respectively. These effects are concentrated in dollar appreciations. Our results suggest that global factors reflected in the dollar affect U.S. borrowing costs.
\end{abstract}

Keywords: loan pricing, syndicated loans, dollar, institutional investors, risk taking.

JEL Classification: F15, G15, G21, G23

*Meisenzahl: Federal Reserve Bank of Chicago. Address: 230 South LaSalle Street, Chicago, IL 60604. Email: ralf.meisenzahl@chi.frb.org. Niepmann: Board of Governors of the Federal Reserve System. Address: 20 an C Streets, Washington, DC 20551. Email: friederike.niepmann@frb.gov. Schmidt-Eisenlohr: Board of Governors of the Federal Reserve System. Address: 20 an C Streets, Washington, DC 20551. Email: tim.schmidt-eisenlohr@frb.gov. We thank seminar participants at the Bank of Ireland, CEPR "WE ARE" series, Chicago FED, Federal Reserve Board, and Whitman SOM for helpful comments and suggestions as well as Wenxin Du for making available some data used in this research. Annie McCrone provided outstanding research assistance. The opinions expressed are those of the authors and do not necessarily reflect the view of the Board of Governors, the Federal Reserve Bank of Chicago or the staff of the Federal Reserve System. 


\section{Introduction}

The supply of credit to the $\$ 1.2$ trillion U.S. leveraged loans market crucially depends on funding from institutional investors (Ivashina and Sun, 2011; Irani et al., forthcoming). As these institutional investors invest globally (e.g. insurance companies), raise capital globally (e.g. CLOs) or both (e.g. mutual funds, hedge funds), they are sensitive to global developments. Specifically, global investors' demand for leveraged loans responds to dollar movements. Figure 1, showing that dollar appreciations are associated with lower nonbank shares in newly formed syndicates, provides the first piece of suggestive evidence for this claim. ${ }^{1}$ In this paper, we show that, as a consequence of global demand linkages, global developments reflected in the dollar directly affect the borrowing costs of U.S. corporations.

While a vast literature studies the effects of lender and borrower characteristics or lender relationships on loan pricing, the effects of global developments on loan pricing are poorly understood. ${ }^{2}$ Furthermore, the direct effect of dollar appreciations on U.S. borrowers adds a new aspect to the recent international finance literature on "global financial cycles". Since the global financial crisis, the dollar has been shown to be a key variable affecting this cycle. $^{3}$ So far, this literature has documented how dollar cycles affect nonU.S. countries. This paper shows that, through borrowing costs for risky

\footnotetext{
${ }^{1}$ The sharp drop in the nonbank share in late 2011 can be attributed to the European debt crisis.

${ }^{2}$ See for example Ivashina (2009) and Santos (2011).

${ }^{3}$ When the dollar appreciates, the capacity to bear risk in global capital markets tends to fall, reflected in lower cross-border lending, larger CIP deviations, and a larger demand for U.S. safe assets.
} 
U.S. corporations, dollar cycles also affect the United States economy. ${ }^{4}$

Identifying the effect of macro-economic or global developments on corporate borrowing costs is challenging and entails endogeneity issues in many settings. To avoid these issues, most prominently those of borrower selection and lower frequency confounding macroeconomic factors, we exploit the fact that leveraged loan terms are adjusted during the syndication process, which is illustrated in Figure 2. ${ }^{5}$ Specifically, we relate movements in the dollar during the syndication process to differences between initial and final loan terms, in a spirit similar to the identification in Bernstein (2015). ${ }^{6}$ Price adjustment during the syndication process (flexes) offer a close-to-ideal setting to study our question. First, initial loan terms are agreed upon by the borrower and the lead arranger before the lead arranger assembles the syndicate - that is, the borrower and key loan characteristics are fixed before demand for a loan realizes, leaving no room for borrower selection. Second, initial loan arranging agreements are designed to provide the lead arranger with strong incentives to obtain the best possible loan terms for the borrower. Therefore, adjustments of loan spreads, original issue discounts (primary market discount), and loan amounts during the syndication process directly reflect changes in the demand from outside investors for the given loan and are independent of lead arranger characteristics. ${ }^{7}$ Finally, the syndication pro-

\footnotetext{
${ }^{4}$ An exception is Niepmann and Schmidt-Eisenlohr (2019), who show that U.S. banks' lending volumes and secondary market prices for corporate loans also move with the dollar.

${ }^{5}$ For more details on the syndication process, see Bruche, Malherbe, and Meisenzahl (forthcoming).

${ }^{6}$ Bernstein (2015) uses stock market movements during the IPO book building process as instrument for the completion of IPOs.

${ }^{7}$ Berg, Saunders, and Steffen (2016) document that discounts, sometimes labeled fees, play a significant role in loan pricing.
} 
cess takes about two weeks, allowing us to use daily frequency data to tightly identify the effect of dollar movements on prices and quantities, in contrast to other studies focusing on quantities at the monthly or quarterly frequencies, which may be affected by other macroeconomic factors.

We postulate that dollar appreciations lower the demand for risky assets and derive testable hypotheses from book building theory applied to the loan syndication process based on Bruche, Malherbe, and Meisenzahl (forthcoming). First, changes in the effective spread during the syndication process should be positively related to dollar movements. Second, changes in loan amounts should be negatively related to dollar movements. Third, underpricing, the difference between the primary market price and the first secondary market price, should be negatively related to dollar movements.

Our main data source to test these hypotheses is the Leveraged Loan Commentary and Data (LCD) that provides us with data on syndicated leveraged loans from 2009-2019. In our main analysis, we keep only U.S. borrowers. The data include the loan launch date, original (talk) loan terms (amount, spread, original issue discount (OID), purpose and other loan characteristics), adjustments to pricing terms (spread flex, OID flex) and to the loan amount (amount flex) as well as the respective flex dates - the date on which the loan started trading, and the first secondary market price.

The main explanatory variable is the change in the broad dollar index during the syndication process for loans to U.S. corporations. ${ }^{8}$ We construct this change as the difference in the broad dollar index between the start of the book building process (launch date) and the date of pricing flexes (spread

\footnotetext{
${ }^{8}$ The broad dollar index is a trade-weighted average of the foreign exchange value of the U.S. dollar against the currencies of major U.S. trading partners.
} 
and/or OID). The key outcome variable to test our first hypothesis is the change in the effective spread (spread + OID/4) during the book building process. ${ }^{9}$ We regress the change in the effective spread on the change in the dollar index and, controlling for a rich set of loan characteristics such as the initial (talk) loan spread, find that a one standard deviation change (about one point) in the dollar index increases the final effective spread by 6 basis points (bps). This increase is statistically significant and economically meaningful, especially when considering that, on average, flexes to the effective spread occur within 12 days from the loan launch date. When allowing for asymmetric effects for dollar index increases and decreases, we find that a one point increase in the dollar index is associated with a 15 bps increase in the effective spread flex. These results represent the first evidence that global shocks are transmitted through the dollar to borrowing costs of U.S. corporations.

For context, we compare the estimated 15 bps increase in loan spreads at origination to the response of secondary market prices of high-yield bonds. Figure 3 shows that high-yield spreads on corporate bonds increased from 350 bps in mid-2014 to 800 bps in December 2015, while the dollar index increased by 21 points, a 21 bps increase in spreads for a one point increase in the dollar index, suggesting that primary and secondary market responses are comparable in magnitude. ${ }^{10}$

Our primary market pricing result is robust to including loan and bor-

\footnotetext{
${ }^{9}$ We follow the market convention and ignore discounting. The typical maturity of a term loan is 5 years. However, these loans are often refinanced earlier, so that the effective maturity is closer to 4 years.

${ }^{10}$ The appendix shows the time series for the changes in both series. The correlation between the changes in the two series is 0.5 .
} 
rower characteristics as well as lead arranger fixed effects. To ensure that our results are not driven by U.S. developments, we also control for changes in the $\log$ VIX, the 2-year Treasury yield, the US term spread, the 3-month U.S. Libor, the AAA-BBB corporate bond spread, the Aruoba-Diebold-Scotti Business Conditions Index, and risk aversion and economic uncertainty from Bekaert, Engstrom, and $\mathrm{Xu}$ (2019). ${ }^{11}$ We find that the coefficient on the changes in the dollar index remains unchanged.

While we focus on U.S. borrowers only, one concern is that exposure to dollar movements through imports or exports could be driving our results. Such exposure would make borrowers' credit risk sensitive to dollar movement and, therefore, affect loan pricing. Our results are robust to restricting the sample to loans to non-financial corporations and to non-tradable industries. The estimate coefficients are in magnitude similar to the full sample. Hence, international trade exposures do not account for our results.

One potential channel through which dollar movements could affect borrowing costs is lead arranger's balance sheet exposures to dollar movements. ${ }^{12}$ Consistent with dollar movements indicating investors' demand for loans, we find that interactions of U.S. lead arranger characteristics with dollar movements have no effect on flexes. Non-U.S. lead arrangers do not drive our results either. One reason for this finding is that arranging agreements provide strong incentives for the lead arranger to obtain the best loan terms for the borrower. Indeed, we find that the changes to spreads during the book building process are independent from lenders' balance sheet exposures

\footnotetext{
${ }^{11}$ The Aruoba-Diebold-Scotti Business Conditions Index is designed to track real business conditions at high observation frequency.

${ }^{12}$ See Bruno and Shin (2015).
} 
to dollar movements. We therefore conclude that the effect of the dollar on U.S. borrowing costs is driven by changes in the demand from investors.

Next, we test our second hypothesis stating that loan amounts are negatively related to dollar movements. Book building theory predicts that when investors indicate low demand, the loan amount should be rationed (Benveniste and Spindt, 1989). We find that loans that are syndicated during a dollar appreciation the loan amount is decreased during the syndication process and are less likely to exhibit a positive amount flex. A one standard deviation (about 1 point) increase in the broad dollar index is associated with 2 percent (\$8 million) decrease in the loan amount. These results constitute corroborating evidence that dollar appreciations indicate a reduction in investors demand for leveraged loans and the transmission of global shock to U.S. borrowers.

We then provide additional evidence that the dollar affects loan demand by studying how dollar movements change loan syndicate participants' rents, measured as underpricing. By doing so, we test our third hypothesis. During the book building process, arrangers incentivize participants to reveal their demand for a loan by promising a rent for primary market participation. This rent takes the form of underpricing - that is, the primary market price is below the first secondary market price. ${ }^{13}$ We find that a one standard

\footnotetext{
${ }^{13}$ To reveal high demand, total rents - underpricing multiplied with amount allocated to a participant-must be high. However, high demand usually leads to over-subscription, and therefore to lower allocated amounts and higher underpricing. Conversely, low demand increases allocated loan amounts and hence, arrangers can reduce underpricing while maintaining incentives to truthfully reveal demand during the book building process (Benveniste and Spindt, 1989; Bruche, Malherbe, and Meisenzahl, forthcoming). Moreover, once the loan terms have been finalized but before the loan is actively traded in the secondary market, movements in the dollar affect participants through their effects on the secondary market price. Specifically, a dollar appreciation is associated with a decline in
} 
deviation increase in the dollar index in the period between the launch date and the first secondary market quote reduces underpricing by 2 percent. As for spreads and loan amounts, the effect is larger for dollar appreciations. The point estimate increases to $7 \mathrm{bps}$ for a one point dollar appreciation.

To shed some light on the reasons why the dollar is associated with the demand for risky assets, we include covered interest rate parity (CIP) deviations - a proxy for financial intermediary arbitrage capital (Avdjiev et al., 2019) - and the Treasury basis - a proxy for global demand for safe assets (Jiang, Krishnamurthy, and Lustig, 2018) in the regressions. Controlling for both, we find that the effect of dollar movements on spreads is unchanged and that changes in CIP deviations have an independent, additional effect on spreads of U.S. corporate borrowers. The unchanged dollar effect on spreads suggests a very tight link between the dollar and risky asset demand, beyond the channels uncovered in the above papers. Independent of the exact channels that link the dollar to investor demand for risky assets, the dollar reflects the global price of dollar liquidity, which is affected by global factors. Therefore, the dollar transmits global developments to U.S. borrowers and the broader U.S. economy.

We contribute to several strands of the literature. First, we contribute to the understanding of the dollar's role for asset markets. Avdjiev et al. (2019) document that a stronger dollar is associated with larger deviations from covered interest parity and less cross-border bank lending. Jiang, Krishnamurthy, and Lustig (2018) find that the dollar appreciates with the global demand for U.S safe assets. Niepmann and Schmidt-Eisenlohr (2019) show secondary market loan prices (Niepmann and Schmidt-Eisenlohr, 2019). 
that dollar appreciations reduce secondary market loan prices and credit supply from banks that follow an originate-to-distribute model. Lilley et al. (2019) find that after the 2007-08 financial crisis the dollar co-moves with global risk measures. ${ }^{14}$ Our high frequency results that dollar appreciations lead to higher loan spreads are consistent with the view that the US dollar is an indicator for the global demand for risky assets and that global shocks affect U.S. domestic borrowing costs.

Second, we add to the literature on the syndication process and loan prices. Ivashina and Sun (2011) show that loans that were syndicated during times of lower inflows to funds take longer to syndicate and have higher spreads. Bruche, Malherbe, and Meisenzahl (forthcoming) use the LCD data to show that lead banks hold larger loan shares when investors demand is low, using flex incidences as proxy for low demand. We add to their findings by linking flex incidence to movements in the dollar index and therefore show how global risk sentiment and global risk-taking capacity affect loan prices for corporations. ${ }^{15}$

Third, we add to the growing literature that emphasizes the role of nonbanks and institutional investors in lending markets. Bord and Santos (2012). Irani et al. (forthcoming), and Lee et al. (2019) document that nonbank participants now account for 80 percent of leveraged loan holdings and that nonbanks hold the most risky loans in this segment. Since collateralized

\footnotetext{
${ }^{14}$ Jiang, Krishnamurthy, and Lustig (2018) argue that changes in the convenience yield assigned by foreign investors to U.S. Treasuries drive dollar movements.

${ }^{15}$ Since we only use within-loan variation, we implicitly control for other factors affecting loan pricing. For instance, Ivashina (2009) documents the impact of asymmetric information between the syndicated lead and participants on spreads. Santos (2011) links the lead bank's financial health to syndicated loan spreads.
} 
loan obligations (CLOs) and mutual funds cannot participate in the primary market they often pre-arrange buying loan shares from participating banks, who originate to distribute these shares. Consistent with this originateto-distribute model, Lee, Liu, and Stebunovs (forthcoming) document the increasing share of nonbanks directly after the syndication process is completed. ${ }^{16}$ Our findings show that the US dollar is an indicator for the demand of such investors for risky assets.

The remainder of the paper is organized as follows. Section 2 describes our data. In section 3, we develop our testable hypothesis. The empirical results are presented in section 4 . In section 5, we assess the effects of CIP deviations and movements in the Treasury basis. Section 6 concludes.

\section{Data}

Our main data source is S\&P Capital IQ's Leveraged Commentary and Data (LCD). LCD contains detailed data on leveraged loans, their characteristics, and their syndication process. The data set includes syndicated loans with either a non-investment-grade rating, or with a first or second lien and a spread of at least 125 basis points over LIBOR. ${ }^{17}$

In our analysis, we focus on loans originated between 2009 and 2019 for two reasons. First, a crucial measure of loan riskiness, the talk yield - the loan yield used by the lead bank to start the book-running - is only consistently available from 2009 on. Second, by excluding prior years, we ensure

\footnotetext{
${ }^{16}$ However, there is little evidence that nonbank participation increases adverse selection (Benmelech, Dlugosz, and Ivashina, 2012).

${ }^{17}$ Figure A1 shows the distribution of loan ratings for the sample.
} 
that our results are not driven by the 2007-08 financial crisis. In addition, we only keep U.S. borrowers to exclude the possibility that borrowers' credit risk is directly affected by dollar movements. ${ }^{18}$

Figure 4 shows the monthly number of loans and monthly total loan amounts in the institutional leveraged term loan market during the sample period. While leveraged loan originations were subdued at the beginning of the sample, we observe on average 58 loans per month. ${ }^{19}$ Over the sample period, the loan amounts add up to $\$ 2.5$ trillion.

Our main variables of interest are the adjustments (flexes) to the spread, the original issue discount, the loan amount, and the first secondary market loan price. The data contain the corresponding launch, flex, and break dates of these variables. Figure 5 shows the incidences of positive (negative) flexes to the effective spread and the loan amount. The figure shows that adjustments to loan terms are common. Moreover, positive and negative flex incidences exhibit a clear, negative correlation for both effective spread flex and amount flex.

Using the launch date, the flex date, and the date of the first secondary market price, we construct changes in the broad dollar index for the time from launch date to flex date and from flex date to first secondary market price date. The broad dollar index is a trade-weighted dollar exchange rate index calculated and published as part of the weekly H.10-Foreign Exchange Rate

\footnotetext{
${ }^{18}$ To identify U.S. borrowers in the LCD data, we merge LCD data with Dealscan data and information from the Loan Syndications and Trading Association (LSTA).

${ }^{19}$ In late 2015/early 2016 the primary market for syndicated loans effectively shut down in the wake of a failed syndication. The arrangers were not able to assemble a syndicate to finance the take-over of Veritas. The low demand for this loan, which market participants attributed in hindsight to CLO industry concentration limits (preventing CLOs from investing in this deal), as well as uncertainty about CLO oil exposures spooked investors.
} 
release by the Board of Governors of the Federal Reserve System. ${ }^{20}$ Table 1 presents the summary statistics for the LCD sample, the broad dollar index, and additional control variables, including U.S. financial market variables and bank balance sheet variables. ${ }^{21}$

\section{Hypothesis Development}

In the development of our testable hypothesis, we focus on the implications of book building theory because Bruche, Malherbe, and Meisenzahl (forthcoming) document that syndication is a book building process. ${ }^{22}$ We first briefly summarize the syndication process and then derive testable hypotheses.

\section{The Syndication Process}

The syndication process, illustrated in Figure 2, starts with borrowers soliciting bids including pricing and risk-sharing provisions from arrangers. The borrower awards the mandate to the preferred arranger. The arranger then proposes a facility agreement that includes all loan terms such as the interest rate, the original issue discount, covenants, and repayment options and uses this agreement to market the loan to investors.

The marketing or book running takes place in at least one round. In

\footnotetext{
${ }^{20}$ The trade partners included in the broad dollar index calculations are the Euro Area, Canada, Japan, Mexico, China, United Kingdom, Taiwan, Korea, Singapore, Hong Kong, Malaysia, Brazil, Switzerland, Thailand, Philippines, Australia, Indonesia, India, Israel, Saudi Arabia, Russia, Sweden, Argentina, Venezuela, Chile, and Colombia.

${ }^{21}$ All variables are described in Appendix A, table A1.

${ }^{22}$ For detailed description of the syndication process, see Bruche, Malherbe, and Meisenzahl (forthcoming). For more details and test of book building theory especially in the context of IPOs, see Benveniste and Spindt (1989), Hanley (1993), and Cornelli and Goldreich (2003).
} 
each round, the arranger proposes a facility agreement including all loan terms such as the pricing to investors. If, given proposed loan terms, there is sufficient demand, the loan is originated at those terms. If the demand from the loan is higher or lower, then there is another round. Based on demand that realized with the last set of loan terms, the arranger "flexes," that is, adjusts the terms accordingly. For instance, if demand was low, then the arranger may increase the interest rate or decrease the loan amount in the next round. The ability to flex, the range of flexes, and the consequences of flexes for the arranger's fee are part of the risk-sharing in the contract between borrower and arranger. The process continues until the loan is originated. After the borrower received the funds, the loan starts trading in the secondary loan market.

A crucial feature of the arranger-borrower agreement is the way arrangers are incentivized to obtain the best loan terms possible for the borrower. The total (final) arranging fees depend on how flex provisions are used. Specifically, to ensure that an arranger exerts effort in the book building process, if the spread is flexed down during the syndication process, the arranger receives part of the borrower's interest rate cost saving as additional fee. However, if the spread needs to be flexed up during the syndication process to place the loan, the borrowers gets partially compensated for this extra interest rate cost by a reduction in the arranging fee. The average per-loan fee income, about 2-3 percent of the loan amount, generated over the relatively short syndication process dwarfs any potential additional interest income on the retained loan share, on average 5 percent for term loans (Lee et al., 2019). In other words, the final fee (payoff) of the arranger is, to first order, a 
function of loan term adjustments and final loan terms that the borrower receives. ${ }^{23}$ As such, the changes in loan terms during the book building process should be independent from the lead arranger's balance sheet.

\section{Testable Hypothesis}

Our analysis of the effect of dollar movements on loan spreads is motivated by an emerging literature that highlights that the dollar is an indicator of global risk-taking capacity and therefore reflects the global demand for risky assets. Avdjiev et al. (2019) show that dollar appreciations reduce crosscountry dollar lending. Niepmann and Schmidt-Eisenlohr (2019) show that such movements also reduce the credit supply of U.S. banks to U.S. corporations because of lower demand for loans by institutional investors. It then follows that if the dollar appreciates during the syndication process of a loan, demand for the loan should be lower. As explained above, in this case the effective spread (spread + OID/4) should be increased to entice investors to participate in the syndicate.

Hypothesis 1. On average, the flex in the effective spread is positively related to dollar appreciations.

Book building theory also states that investors will be rationed on cold (low demand) loans (Hanley, 1993; Bruche, Malherbe, and Meisenzahl, forthcoming). If the dollar is indeed an indicator for the global demand for risky assets, dollar appreciations should indicate lower demand and, as a result, the arranger raises less funds by reducing the total loan amount.

\footnotetext{
${ }^{23} \mathrm{~A}$ detailed example can be found in Bruche, Malherbe, and Meisenzahl (forthcoming).
} 
Hypothesis 2. On average, the flex in the loan amount is negatively related to dollar movements.

This hypothesis is distinct from the reduction in bank credit supply documented in Niepmann and Schmidt-Eisenlohr (2019), as here we study withinloan variation rather than the total amount lent by a bank to a corporation. ${ }^{24}$ In their setting, the reduction in lending by one bank could be substituted by credit from a different bank or a nonbank leaving total credit available to the corporation unchanged. In contrast, the participants in the syndicated loan market represent the set of lenders willing to lend to larger corporations, and the loans are so large that one single lender would typically not be willing to originate the loan on their own. Hence, substitution through other loans is unlikely and as a result, the total loan amount of the syndicated loan is reduced. To be clear, corporations could in principal access other sources of debt such as bonds, but most borrowers in the syndicated loan market do not issue bonds, and raising additional funds from other sources such as private equity may be challenging at a high frequency.

To induce investors to reveal their true demand for a syndicated loan, the arranger has to reward investors with higher rents when their demand is high and similarly, lower rents when their demand is low. As in equity or bond placements, investors in the syndicated loan market are compensated for revelation of their demand through underpricing - that is, primary market participants pay less for a unit of the loan than the first secondary market

\footnotetext{
${ }^{24}$ Niepmann and Schmidt-Eisenlohr (2019) also decompose effects into an extensive and intensive margin and find that declines in bank lending are driven by a reduction in the number of loans (the extensive margin).
} 
price. ${ }^{25}$ The total investor rent is underpricing multiplied with the amount allocated to the investor. Since the loan size is often fixed, investors will receive smaller than requested loan amounts when demand is high. To ensure incentive-compatibility, the per-unit compensation (underpricing) needs to be increased. Conversely, if demand is low, each investor receives a larger share and hence, the per-unit underpricing can be lowered without violating the incentive constraint of investors. ${ }^{26}$

In the context of our paper, we anticipate that dollar appreciations indicate a reduction in global demand for risky assets. This lower loan demand then requires less per-unit rent to induce investors to reveal their demand. Taken together, loans syndicated during dollar appreciations should be less in demand and therefore should require less per-unit rent — that is, they should be underpriced less.

Hypothesis 3. On average, underpricing is negatively related to dollar appreciations.

We will investigate dollar movements during different stages of the syndication process. If underpricing responds to dollar movements up to the effective spread flex date, then this hypothesis reflects low demand for this specific loan on the primary market (Benveniste and Spindt, 1989; Hanley, 1993). If dollar movements after the effective spread flex date affect underpricing, then lower primary market participant rents are due to lower secondary market prices, consistent with the secondary market channel high-

\footnotetext{
${ }^{25}$ For details, see Benveniste and Spindt (1989); Hanley (1993); Bruche, Malherbe, and Meisenzahl (forthcoming).

${ }^{26}$ The presence of a limited loan amount also implies that prices only adjust partially to new information (Benveniste and Spindt, 1989; Hanley, 1993).
} 
lighted by Niepmann and Schmidt-Eisenlohr (2019).

\section{Corporate Borrowing Costs and the Dollar}

In this section, we conduct our empirical analysis. We first study the effect of changes in the dollar during the book-running process on effective loan spreads and whether these effects vary by loan characteristics. We then turn to loan amounts. Last, we analyze whether underpricing - the rent earned by primary market syndicate participants - is affected by changes in the dollar.

\subsection{The Dollar and Syndicated Loan Terms}

We start our empirical analysis by assessing the effect of changes in the dollar on the change in the effective spread. The effective spread is easy to calculate since syndicated loans have a floating rate, typically comprised of LIBOR as base rate and the effective spread (spread + OID/4). ${ }^{27}$ To isolate this effect, we focus on dollar movements during the syndication process - that is, we focus on the changes in the effective spread during the syndication process, while holding borrower and loan characteristics constant. By focusing on this within-loan variation, we avoid potential borrower selection and can separate the effect of dollar movements as they are orthogonal to other potential loanspecific factors that can explain loan spreads. ${ }^{28}$

\footnotetext{
${ }^{27}$ Later, we directly control for an extensive set of macroeconomic, financial, and monetary controls, including the 2-year Treasury yield and the term spread in case that changes in the base rate affect the effective spread.

${ }^{28}$ For instance, Ivashina (2009) studies the effect of asymmetric information on loan spreads. Our identification strategy is similar to Bernstein (2015), who uses stock market movements after the initial IPO filings as an instrument for IPO completion.
} 


\section{Effective Spread Adjustments}

To test our first hypothesis that the flex in the effective spread is positively related to dollar appreciations, we begin by assessing whether the probability of observing a positive or negative effective spread flex depends on dollar index movements in the first 12 days after the launch date of the loans. ${ }^{29}$ We estimate the following regression:

$$
\mathbb{1}_{\text {Effective } \text { Spread }_{i, \Delta t}}=\beta \Delta \text { Dollar }_{\Delta t}+\gamma X_{i}+\epsilon_{i, \Delta t}
$$

The key variable of interest is the change in the broad dollar index in the first 12 days after the launch date of the loan $\Delta$ Dollar $_{i, \Delta t}$. We add loancontrol variables $X_{i}$ (the talk (initial) loan amount, the talk (initial) spread, maturity, and dummy variables for whether the loan is sponsored, the loan is rated, the loan is a cov-lite loan, and the loan is a middle market loan, as well as fixed effects for the lead agent, the borrower industry, and the loan purpose).

Table 2 shows the results from estimating equation 1 . Consistent with hypothesis 1, column 1 indicates that increases in the dollar increase the probability of observing a positive flex in the effective spread - that is, an increase in the effective interest rate on the loan. A one standard deviation increase in the dollar index (0.91 point) increases the probability of observing a positive spread flex by 17 percentage points. At the same time, increases in the dollar index reduce the probability of observing a negative effective spread flex (column 2). This pattern is also consistent with figure 5 that

\footnotetext{
${ }^{29}$ Twelve days is the average time between the launch date of a loan to flexes for loans with flexes.
} 
shows a negative correlation between positive and negative flexes. Restricting the sample to loans with a flex date, we find that these effects are more pronounced (columns 3 and 4). These results show that borrowers are more likely to face higher-than-expected effective interest rates on syndicated loans if the dollar appreciates during the first two weeks of the syndication process. This finding is consistent with the view that an appreciation of the dollar indicates lower global demand for risky assets.

Having established that positive flexes in the effective spread are more likely with dollar index increases, we now inspect the relationship between the size of the effective spread flex and dollar movements. Figure 6 plots the data binned by dollar index movements and the corresponding effective spread flex. There is a clear correlation between effective spread flexes and dollar movements. To quantify the effect of dollar movements on the effective spread flex, we estimate the following regression:

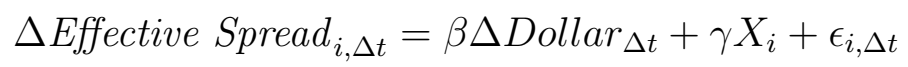

The key variable of interest is now the change in the broad dollar index for the time from the launch date of loan $i$ to the flex date of loan $i \Delta$ Dollar $_{i, \Delta t}$ (or over the first 12 days after the launch date if not all loans have a flex date). Control variables and fixed effects are as before.

Table 3 shows the results from estimating equation 2. Since not all loans have a flex date, the change in the dollar index is calculated over the first 12 days after the launch date, the average time to flex for loans with flexes. Column 1 shows the estimated effect without control variables for the sample of all loans. The estimated effect is highly statistically significant and 
suggests that a one standard deviation (0.91 points) increase in the dollar index increases the effective loan spread by 2.4 basis points. In column 2 , we add loan-level controls, including the talk (initial) spread to account for the ex-ante riskiness of the loan, and find that the coefficient on the dollar index change and its statistical significance remains unchanged. This result is robust to the inclusion of borrower industry, loan purpose and lead bank fixed effects (column 3).

We repeat these regressions for the sample of loans for which we observe the flex date, and the change in the dollar index is calculated from the launch date to the flex date. Table 3, column 4 shows the estimated effect without control variables. Compared to column 1, the coefficient is more than twice as large. A one standard deviation increase in the dollar index increases the effective loan spread by 6 basis points. Adding controls (column 5) and fixed effects (column 6) does not change the estimated effect. The stability of the coefficient across specifications suggests that changes in the effective spread are in fact driven by changes in the dollar index and not by unobserved loan characteristics. ${ }^{30}$

A potential concern with our specification and interpretation is that changes in the dollar index could reflect other macroeconomic developments such as increases in economic uncertainty or other relevant news. To ensure that our results are not driven by such developments, we augment equation 2 by adding the changes in a large set of U.S. variables. Specifically, we use changes in the log VIX, the US Corporate AAA-BBB spread, the

\footnotetext{
${ }^{30}$ In unreported results, we find no evidence for heterogeneous effects of dollar movements by credit rating, talk spread, or loan size. One potential reason is that leverage loans are deemed to be a non-investment grade asset class and changes in the risk sentiment reduce the demand for the whole assets class and not just for the riskiest parts.
} 
2-year Treasury yield, the U.S. term spread, the 3-month U.S. Libor, and the Aruoba-Diebold-Scotti Business Conditions Index as proxies for U.S. financial and macroeconomic conditions. ${ }^{31}$ Since syndicated term loans are floating rate loans, changes in the level of short-term interest rates should not affect the spread.

Table 4 shows the results of adding changes in macroeconomic variables to equation 2 . In columns 1 and 2, we subsequently add controls for changes in U.S. macroeconomic conditions and loan controls. When adding all macroeconomic controls, the coefficient shown in column 2 (5.471) is only slightly smaller compared to the baseline results without macroeconomic controls (6.496, shown in Table 3, column 5). Adding industry, purpose, lead bank fixed effect does not not materially affect the size of the estimated coefficient (column 3) either. Controlling for syndication quarter fixed effects, which partly absorb the changes in the dollar index, reduces this coefficient in size, but the effect remains sizable and statistically significant (column 4). Taken together, the results indicate that changes in the dollar index do not simply reflect other observable changes in the U.S. financial and macroeconomic environment. ${ }^{32}$

\footnotetext{
${ }^{31}$ We include the VIX as measure of uncertainty in the economy. The US Corporate AAA-BBB spread is a proxy for the risk premium with compressed spreads indicating a low risk premium. We include the 3-month U.S. Libor and the 2-year Treasury yield as measures of short-term and medium-term interest rates, and the U.S. term spread as measure of future economic conditions. The Aruoba-Diebold-Scotti Business Conditions Index captures U.S. business conditions at high frequency.

${ }^{32}$ In section 5, we demonstrate the robustness of our results to controlling for changes in CIP deviations and the Treasury basis. In addition, table B3 in the appendix includes changes in risk aversion and economic uncertainty from Bekaert, Engstrom, and $\mathrm{Xu}(2019)$ as control variables, with no effects on the magnitude nor the significance of the dollar coefficient. In unreported results, we find that the inclusion of changes in Japanese macroeconomic conditions also does not affect our main result.
} 


\section{Controlling for International Exposures}

Changes in the broad dollar may directly affect a borrower's revenues and costs if the borrower imports, exports, or has cross-border financial activities. This may in turn affect the ability of a borrower to repay a loan and hence the credit spread charged by banks. We address this concern by dropping loans for financial corporations and by showing that our results hold in the sample of firms in non -tradable sectors.

Table 5 shows results for all loans with a flex. ${ }^{33}$ Columns 1 and 2 show the baseline results when excluding the financial sector (all SIC codes starting with 6), as banks and other financial institutions often transact across borders. Our main results are unaffected by the exclusion of the financial sector.

To ensure that our results are not driven by the trade exposures of borrowers, we split the sample into non-traded and traded industries. Columns 3 and 4 show results for the baseline specification for industries that do not export or import (as before, we are also excluding the financial sector). The baseline results remain, which implies that even firms with no exports or imports face higher financing costs when the dollar appreciates. Finally, columns 5 and 6 repeat the baseline specification for all firms in industries with some exports or imports. While the point estimates are somewhat larger than those in columns 3 and 4, they are not significantly different.

We conclude that the effect we uncover is neither driven by export or import exposures of borrowers nor is it driven by financial sector borrowers

\footnotetext{
${ }^{33}$ Note that industry fixed effects in table 5 are based on borrowers' SIC codes. SIC codes are not available for all borrowers in the dataset. Therefore industry fixed effects in other tables are implemented using a less granular industry classification that is available in the LCD data.
} 
with financial links across borders.

\section{The Role of Lead Agent Characteristics}

While studying price adjustments during the syndication process alleviates concerns about borrower selection, it is possible that time-varying lead arranger characteristics affect price adjustments during the syndication process - that is, flexes could be driven by dollar exposures of lead arrangers' balance sheets rather than by the demand for the loans from investors. For instance, if lead banks fund loans through wholesale dollar markets, sudden dollar movements affect the lead arranger's funding cost. However, if the dollar reflects investor demand, then lead arranger characteristics should not affect the flexes.

The arranger agreement is designed to provide the lead arranger with strong incentives to obtain the best possible loan terms for the borrower. As described in section 3, the arranger agreement makes the lead arranger's payoff a function of flexes during the syndication process. Moreover, lead arrangers only retain a small loan share, reducing the benefits of higher interest rates for the arranger. Taken together, this incentive structure implies timevarying lead arranger characteristics should not matter for effective spread flexes.

To test whether lead arrangers' characteristics affect flexes, we draw on balance sheet information contained in the Y-9C reports of 21 U.S. lead arrangers. ${ }^{34}$ These 21 lead agents arrange around 84 percent of the loans in the sample. We compute lagged four-quarter rolling averages of the following

\footnotetext{
${ }^{34}$ Foreign banks that do not operate BHCs or IHCs in the U.S. and nonbanks such as Nomura or Jefferies Securities do not have to file regulatory reports.
} 
lead-agent characteristics: Tier 1 capital ratio, retail deposit share, liquid asset ratio, share of loans held for sale (LHS share), non-interest income ratio, share of trading revenues in non-interest plus interest income, and ratio of net charge-offs to total loans. ${ }^{35}$

We conduct our analysis in parallel to column 6 of table 3 . We use the subsample of loans to U.S borrowers that have a flex date and include loan controls as well as industry, purpose and lead fixed effects. In addition, we interact the lead bank characteristics with the change in the dollar index and include the linear and the interaction terms in the regressions.

Table 6 shows the results. Consistent with our hypothesis that lead arranger characteristics do not affect flexes, none of the interactions terms are statistically significant. Moreover, for all specifications, the point estimate on the change in the dollar index is very similar to the baseline point estimate shown in column 6 of table 3 . We therefore conclude that lead arrangers' exposure to dollar movements do not play a role for price adjustments during the syndication process. ${ }^{36}$

To ensure that our results are not driven by non-U.S. lead arrangers that arguably are exposed to dollar movements by having to raise dollar funding for syndicated loans, we now test for differences in the effect of the dollar on the effective spread flex between U.S. lead arrangers and lead arrangers with foreign parents. Accordingly, we define a dummy variable Foreign Lead Arranger Parent that takes the value of 1 if the lead arranger

\footnotetext{
${ }^{35}$ Details on the construction of the lead-arranger variables can be found in table A1.

${ }^{36} \mathrm{We}$ ran different variants of the effective spread flex regressions, including various fixed effects as controls and using a sample that includes all loans. The interaction terms between the dollar and lead arranger characteristics were not statistically significant in these alternative specifications.
} 
is owned by a foreign parent and interact this dummy with the change in the dollar index. We include these variables in the baseline regression.

Table 7 shows the results. As indicated by columns 1 and 2, the point estimate on Foreign Lead Arranger Parent is economically small and statistically insignificant for the full sample. This finding holds in the subsample of loans with flexes (columns 3 and 4).

In sum, neither lead arranger balance sheet exposures to dollar movements nor differences in responses to dollar movements between domestic and foreign lead arrangers account for the observed changes in the flexes in response to dollar movement. This finding is consistent with dollar movements reflecting the demand for loans by investors.

\section{Loan Amount Adjustments}

Last, we complement the evidence on loan pricing with evidence on loan amounts. Specifically, when investors' demand for a loan is low, the lead agent should not only increase the effective spread but also decrease the loan amount (Hanley, 1993; Bruche, Malherbe, and Meisenzahl, forthcoming). To test this hypothesis (hypothesis 2) we estimate the following regression:

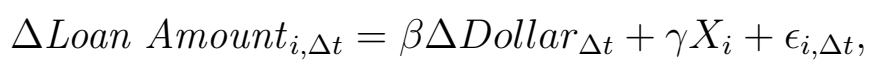

where $\Delta$ Loan Amount ${ }_{i, \Delta t}$ is either the change in the loan amount or an indicator variable that the loan amount was flexed down (up).

Table 8 shows the results from estimating equation 3. Column 1 shows that movements in the dollar index negatively affect loan amounts, but the effect is statistically insignificant. This effect increases and becomes statically 
significant in the subsample of loans with an amount flex, shown in column 2 , to $\$ 8$ million (2 percent).

In column 3 (4), we estimate the propensity of observing a positive (negative) amount flex. A 1 point increase in the dollar index reduces the propensity of observing a positive amount flex, an increase in the loan amount during the syndication process, by 12 percent. However, we do not find evidence that dollar movements affect the propensity of negative spread flexes.

In sum, reductions in loan amount during the syndication process driven by dollar appreciations are consistent with dollar appreciations indicating lower investor demand for risky assets and show that credit supply to large U.S. corporations is critically affected by institutional investors.

\subsection{Dollar Exposure of Syndicate Participants}

We now turn to the effect of changes in the dollar on primary market participant rents. To induce investors in the primary market to reveal their true demand for a loan, lead arrangers have to underprice loans in the primary market relative to the break price - the first quoted secondary market price (Benveniste and Spindt, 1989; Bruche, Malherbe, and Meisenzahl, forthcoming). Underpricing in the syndicated loan market can be measured as follows:

$$
\text { underpricing }=\underbrace{\text { break price }}_{\text {secondary market price }}-\underbrace{(\text { par }- \text { original issue discount })}_{\text {primary market price }} .
$$

After the final loan terms, and therefore the primary market price, have been set, the risk of dollar movements shifts from the borrower to the in- 
vestors before the loan starts trading in the secondary market. Niepmann and Schmidt-Eisenlohr (2019) show that dollar appreciations reduce secondary market prices for syndicated loans in general. ${ }^{37}$ Therefore, dollar appreciations should affect underpricing negatively.

To test our third hypothesis that underpricing is negatively related to dollar appreciations, we estimate the following regression:

$$
\text { Underpricing }_{i}=\beta \Delta \text { Dollar }_{\Delta t}+\gamma X_{i}+\epsilon_{i, \Delta t},
$$

where $\Delta$ Dollar $_{\Delta t}$ is now the change in the dollar index between the flex date (the date of final loan terms) and the break price date (the date of the first secondary market price quote).

Table 9 shows the results of estimating equation 4 . Increases in the dollar during the syndication process are not fully reflected in the effective spread and reduce primary market participant rents (column 2). ${ }^{38}$ The effect is slightly larger when considering the changes over the whole syndication process (column 1). The risk of changes in underpricing after the effective spread is flexed but before the loan starts trading is fully borne by syndicate participants. In fact, increases in the dollar after the flex date also reduce underpricing (column 3) even though the average time from the flex date to the break price date is only one day. This reduction is driven by declines in loan prices on the secondary market in response to dollar appreciations. This finding is consistent with the secondary market channel documented by

\footnotetext{
${ }^{37}$ Irani and Meisenzahl (2017) show that liquidity pressures on banks leads to more loan sales and reduces prices for loans previously held by banks.

${ }^{38}$ This results is consistent with partial adjustment during the book building process (Benveniste and Spindt, 1989; Bruche, Malherbe, and Meisenzahl, forthcoming).
} 
Niepmann and Schmidt-Eisenlohr (2019).

Bruche, Malherbe, and Meisenzahl (forthcoming) report that, on average, underpricing in the syndicated loan market is about 45 bps over a comparable sample period. ${ }^{39}$ Our results therefore suggest that a one standard deviation increase in the dollar index reduces primary market participants' rent by 2 bps.

In sum, the results presented in this section show that movements in the dollar affect primary market participants' rents. Loan interest rates only partially price the changes in the dollar index from the launch date to the flex date. Lower secondary market prices in response to increases in the dollar index can reduce underpricing after the final loan pricing is set.

\subsection{Asymmetric Effect of Dollar Movements}

In this section, we test whether the effects of increases and decreases of the dollar index are symmetric. Figure 6 suggests a potential asymmetry as the correlation between dollar movements and spread flex appears to be stronger for dollar index increases than for decreases.

To test whether the effect of dollar index increases and decreases are symmetric, we estimate the following regression:

$$
\begin{aligned}
\Delta \text { Outcome }_{i, \Delta t} & =\beta_{1} \mathbb{1}_{\Delta \text { Dollar }_{\Delta t}>0} \Delta \text { Dollar }_{\Delta t} \\
& +\beta_{2} \mathbb{1}_{\Delta \text { Dollar }_{\Delta t}<0} \Delta \text { Dollar }_{\Delta t}+\gamma X_{i}+\epsilon_{i, \Delta t}
\end{aligned}
$$

\footnotetext{
${ }^{39}$ This is somewhat higher than the underpricing for bonds (Cai, Helwege, and Warga, 2007).
} 
The regression equation also includes a dummy variable for very small changes in the dollar, meaning $-0.025 \leq \Delta$ Dollar $\leq 0.025$. Table 10 shows the results of estimating equation 5 with changes in the dollar index split into appreciations, dollar depreciations, and very small changes in the dollar. Column 1 shows that our results for the effective spread flex are driven by dollar appreciations rather than depreciations. While the effect of increases in the dollar index $\left(\beta_{1}\right)$ is economically large and statistically significant, the effect of decreases in the dollar index $\left(\beta_{2}\right)$ is economically small and statistically insignificant. This pattern holds for both components of the effective spread flex, the OID flex (column 2) and the spread flex (column 3). The asymmetric effects of dollar appreciations and depreciations are also present in the amount flex (column 4) and in underpricing (column 5).

The economic significance of increases in the dollar index is substantially larger than the average effects estimated before. Specifically, a standard deviation increase in the dollar index increases the spread by 15.2 bps compared to 6 bps shown in table 3, column 5, and the effect on underpricing more than doubles to 6.1 bps compared to 2 bps based in table 9 , column 1 . The effect on the loan amount - a $\$ 8$ million reduction in the loan amounts - is the same as in the linear specification shown in table 8, column 2 .

The asymmetric results indicate asymmetries in the response of institutional investors' loan demand to changes in the dollar. One potential explanation for this could be asymmetric hedging as suggested by Koutmos and Martin (2003). However, since we do not have data on hedging or derivative contracts held by nonbank financial institutions, we cannot test this hypothesis. Future research should investigate the possible causes of the asymmetries 
we document.

\section{CIP Deviations, Safe Asset Demand, and the Dollar}

So far, we have shown that the dollar affects the borrowing costs of U.S. corporations, consistent with the dollar reflecting investor demand for leveraged loans. Why is it that the dollar reflects investors' appetite for risky assets? The literature offers several explanations. ${ }^{40}$

First, Avdjiev et al. (2019) show that the dollar exchange rate is correlated with CIP deviations, which arguably proxy the capacity of financial intermediaries to engage in arbitrage activities. When the arbitrage capital of financial intermediaries globally becomes scarcer, reflected in bigger CIP deviations, the dollar tends to appreciate. Second, Jiang, Krishnamurthy, and Lustig (2018) argue that the dollar appreciates with the global demand for safe assets, finding that convenience yields on U.S. Treasuries correlate positively with the dollar exchange rate. Third, Bruno and Shin (2015) show how global currency-mismatches imply a worsening of financial intermediaries' balance-sheets when the dollar appreciates, tightening value-at-risk constraints and thereby reducing risk-taking. ${ }^{41}$

In the following we test if the first two channels above explain the relationship between the dollar and U.S. borrowing costs. Results are presented

\footnotetext{
${ }^{40} \mathrm{See} \mathrm{Du}$ (Forthcoming) for a review of the literature.

${ }^{41}$ In theoretical work, Gabaix and Maggiori (2015) show how financial intermediaries price currency risk and, thereby, affect the level of exchange rates. Akinci and Queralto (2018), model a two-way relationship between balance sheet strength of borrowers and the dollar.
} 
in Table 11. For ease of comparison, column 1 presents again the baseline results from table 3 , column 6 , showing the effect of changes in the dollar index on flexes. Column 2 adds a measure of CIP deviations, the average five-year dollar Libor cross-currency basis against G10 currencies from Avdjiev et al. (2019). This Libor basis is almost always negative over the sample period. Increases in the Libor basis reflect, on average, smaller CIP deviations and, hence, greater financial intermediary capacity. As expected, an increase in the Libor basis (a less negative Libor basis) is associated with smaller flexes, as indicated by the negative, significant coefficient. However, the inclusion of CIP deviations reduces the coefficient on dollar changes only somewhat and the dollar effect continues to be highly statistically significant. This suggests that the dollar effect on corporate borrowing costs goes beyond any effect that works through the financial intermediary arbitrage capital channel. ${ }^{42}$

Column 3 of table 11 employs changes in the 1-year Treasury basis from Du, Im, and Schreger (2018). ${ }^{43}$ A larger Treasury basis implies that investors are willing to pay a higher premium to hold U.S. Treasuries compared to other safe securities. Accordingly, a higher Treasury basis should be associated with less risk-taking and, hence, larger flexes. However, in contrast to this conjecture, conditional on dollar movements a higher Treasury basis is associated with lower flexes, as column 3 shows. ${ }^{44}$ This finding suggests that

\footnotetext{
${ }^{42}$ In the appendix, table B2, columns 7 and 8 show that CIP deviations have a significant effect on flexes without the inclusion of dollar. Moreover, we can include CIP deviations along with the dollar in all specifications, and both coefficients will always be significant (Results available upon request.) These additional results suggest that CIP deviations affect U.S. corporate borrowing costs independently from the dollar.

${ }^{43}$ We obtain similar results when using 3-month, 2-year, 3-year, 5-year, 7-year, or 10-year treasury basis instead of the 1-year Treasury basis.

${ }^{44}$ In table B2 in the appendix, we show that when including only the Treasury basis, the point estimate is still negative but statistically insignificant, suggesting that safe asset
} 
the dollar effect on corporate borrowing costs is not driven by a differential demand for U.S. safe assets.

Column 4 controls for both CIP deviations and the Treasury basis at the same time. In columns 5, U.S. financial and macroeconomic variables are added. Column 6 incorporates additionally year-quarter fixed effects. The estimated dollar coefficients are hardly changed compared with the equivalent regressions without CIP deviations and Treasury basis.

Besides reflecting financial intermediary capacity, larger CIP deviations imply that the cost of obtaining dollars in swap markets is larger for foreign investors without direct access to dollar funding. Because the U.S. leveraged loan market attracts foreign investors that may finance their investments through FX swaps, larger CIP deviations may make leveraged loans less attractive for this group. Whether CIP deviations affect borrowing costs through this direct link or through a more indirect channel cannot be conclusively answered based on the regressions presented here. In any case, the fact that CIP deviations affect U.S. corporate borrowing costs is additional evidence that U.S. borrowing costs depend on global factors. ${ }^{45}$

If neither the safe asset demand channel reflected in the Treasury nor global financial intermediary capacity reflected in CIP deviations fully explain the effect of the dollar on U.S. corporate borrowing costs, what other channel can connect the dollar to investor demand for risky assets? It is pos-

demand as measured by the treasury basis is of lesser importance for corporate borrowing costs.

${ }^{45}$ Another conjecture is that financial regulation that has reduced financial intermediaries' arbitrage capital may have indirectly increased the borrowing costs for U.S. corporations. In this context, see Eguren-Martin, Ossandon Busch, and Reinhardt (2019) who find that banks reduce their cross-border lending in response to larger CIP deviations. 
sible that changes in the dollar exchange rate alter the risk profile of global investors' portfolios, making them riskier in the spirit of Bruno and Shin (2015). In this case, exogenous shocks to the dollar exchange rate would directly affect investors' risky asset demand and U.S. corporate borrowing costs.

Since we control for U.S. macroecomomic and financial variables, and because of our high-frequency identification and robustness of our results, U.S. factors are unlikely to drive our results. Instead, our results point to a close connection between the dollar exchange rate and investor demand for risky assets. The broad dollar index captures the global price of dollar liquidity and is driven, to a significant degree, by non-U.S. developments. Therefore, regardless of the exact mechanism that links the dollar to the investor demand for risky assets, we conclude that, through the dollar, global shocks transmit to U.S. corporate borrowing costs.

\section{Conclusion}

We show that movements in the dollar index materially affect the corporate borrowing cost and credit supply to U.S. corporate borrowers. Using high frequency data and within-loan identification, we find that the effects are concentrated in increases in the dollar index. These results are consistent with the interpretation that dollar movements reflect changes in global risk sentiment and the global demand for risky assets. As we showed, the relationship between the dollar and borrowing costs persists even when controlling for CIP deviations that capture financial intermediary constraints and the con- 
venience yield that measures the premium associated with holding U.S. safe assets. While it is beyond the scope of our paper to pin down the channels that connect the dollar to investors' demand for risky assets, our results show that through the dollar, which is driven by non-U.S. factors, global factors affect U.S. borrowing costs and through that the broader U.S. economy. 


\section{References}

Akinci, Ozge and Albert Queralto. 2018. "Exchange Rate Dynamics and Monetary Spillovers with Imperfect Financial Markets." Staff Repor 849, Federal Reserve Bank of New York t.

Avdjiev, Stefan, Wenxin Du, Cathrine Koch, and Hyun Song Shin. 2019. "The Dollar, Bank Leverage, and Deviations from Covered Interest Parity." American Economic Review: Insights 1 (2):193-208.

Bekaert, Geert, Eric C. Engstrom, and Nancy R. Xu. 2019. "The Time Variation in Risk Appetite and Uncertainty." NBER Working Papers 25673, National Bureau of Economic Research, Inc.

Benmelech, Efraim, Jennifer Dlugosz, and Victoria Ivashina. 2012. "Securitization without adverse selection: The case of CLOs." Journal of Financial Economics 106 (1):91-113.

Benveniste, Lawrence M. and Paul A. Spindt. 1989. "How investment bankers determine the offer price and allocation of new issues." Journal of Financial Economics 24 (2):343-361.

Berg, Tobias, Anthony Saunders, and Sascha Steffen. 2016. "The Total Cost of Corporate Borrowing in the Loan Market: Don't Ignore the Fees." Journal of Finance 71 (3):1357-1392.

Bernstein, Shai. 2015. "Does Going Public Affect Innovation?" Journal of Finance 70 (4):1365-1403.

Bord, Vitaly M. and Joao A. C. Santos. 2012. "The Rise of the Originate-toDistribute Model and the Role of Banks in Financial Intermediation." Federal Reserve Bank of New York Economic Policy Review 18 (2):21 - 34.

Bruche, Max, Frederic Malherbe, and Ralf R. Meisenzahl. forthcoming. "Pipeline Risk in Leveraged Loan Syndication." Review of Financial Studies .

Bruno, Valentina and Hyun Song Shin. 2015. "Cross-border banking and global liquidity." Review of Economic Studies 82 (2):535-564.

Cai, Nianyun (Kelly), Jean Helwege, and Arthur Warga. 2007. "Underpricing in the Corporate Bond Market." Review of Financial Studies 20 (6):2021-2046.

Cornelli, Francesca and David Goldreich. 2003. "Bookbuilding: How Informative Is the Order Book?" Journal of Finance 58 (4):1415-1443. 
Du, Wenxin. Forthcoming. "Financial Intermediation Channel in the Global Dollar Cycle." 2019 Jackson Hole Economic Policy Symposium Proceedings .

Du, Wenxin, Joanne Im, and Jesse Schreger. 2018. "The US Treasury Premium." Journal of International Economics 112:167-181.

Eguren-Martin, Fernando, Matias Ossandon Busch, and Dennis Reinhardt. 2019. "Global banks and synthetic funding: the benefits of foreign relatives." Bank of England working papers 762, Bank of England.

Gabaix, Xavier and Matteo Maggiori. 2015. "International liquidity and exchange rate dynamics." The Quarterly Journal of Economics 130 (3):1369-1420.

Hanley, Kathleen Weiss. 1993. "The underpricing of initial public offerings and the partial adjustment phenomenon." Journal of Financial Economics 34 (2):231250 .

Irani, Rustom, Rajkamal Iyer, Ralf R. Meisenzahl, and Jose-Luis Peydro. forthcoming. "The Rise of Shadow Banking: Evidence from Capital Regulation." Review of Financial Studies .

Irani, Rustom and Ralf R. Meisenzahl. 2017. "Loan Sales and Bank Liquidity Management: Evidence from a U.S. Credit Register." Review of Financial Studies 30 (10):3455-3501.

Ivashina, Victoria. 2009. "Asymmetric information effects on loan spreads." Journal of Financial Economics 92 (2):300 - 319.

Ivashina, Victoria and Zheng Sun. 2011. "Institutional demand pressure and the cost of corporate loans." Journal of Financial Economics 99 (3):500 - 522.

Jiang, Zhengyang, Arvind Krishnamurthy, and Hanno Lustig. 2018. "Foreign Safe Asset Demand for US Treasurys and the Dollar." AEA Papers and Proceedings 108:537-41.

Koutmos, Gregory and Anna D Martin. 2003. "Asymmetric exchange rate exposure: theory and evidence." Journal of international Money and Finance $22(3): 365-383$.

Lee, Seung Jung, Dan Li, Ralf R. Meisenzahl, and Martin Sicilian. 2019. "The U.S. Syndicated Term Loan Market: Who holds what and when?" FEDS Notes, November 25, 2019. Board of Governors of the Federal Reserve System (U.S.). 
Lee, Seung Jung, Lucy Qian Liu, and Viktors Stebunovs. forthcoming. "Risk Taking and Interest Rates: Evidence from Decades in the Global Syndicated Loan Market." Journal of Banking and Finance .

Lilley, Andrew, Matteo Maggiori, Brent Neiman, and Jesse Schreger. 2019. "Exchange Rate Reconnect." Working Paper 26046, National Bureau of Economic Research.

Niepmann, Friederike and Tim Schmidt-Eisenlohr. 2019. "Institutional Investors, the Dollar, and U.S. Credit Conditions." International Finance Discussion Papers 1246. Board of Governors of the Federal Reserve System (U.S.).

Santos, Joao A. C. 2011. "Bank Corporate Loan Pricing Following the Subprime Crisis." Review of Financial Studies 24 (6):1916 - 1943. 


\section{Figure 1: New Syndicate Composition and Dollar Index}
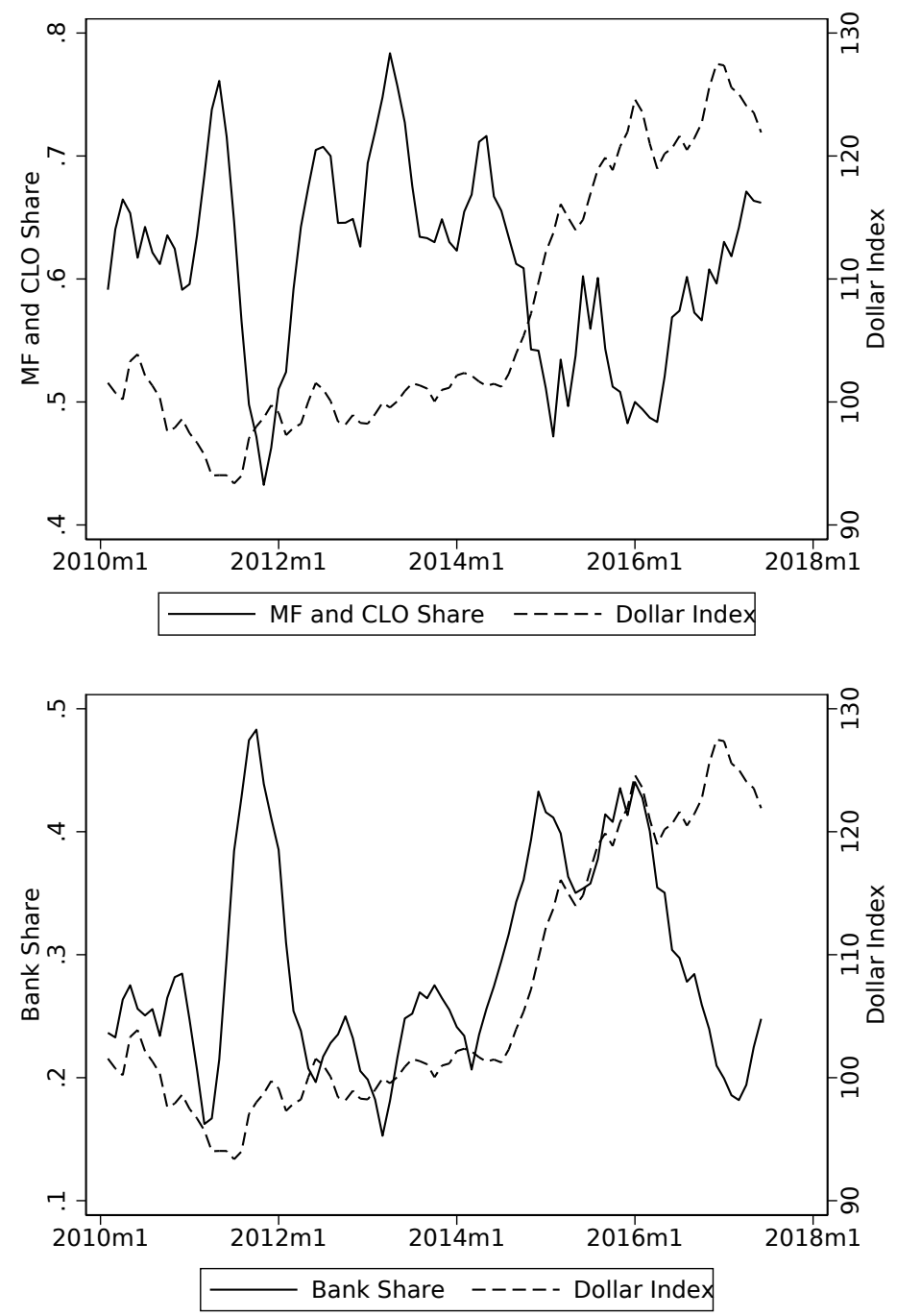

Note: The upper panel figure shows the broad dollar index and the aggregate CLO and mutual fund share in new loan syndicates in the Shared National Credit Program (SNC). The lower panel figure shows the broad dollar index and the aggregate bank share in new loan syndicates. The shares reflect the syndicate composition of new loans originated within the reporting quarter. We drop loans originated within 14 days of the reporting date as they are typically not distributed at the reporting day. Shares series are smoothed over 4 quarters. The correlation of the series with the dollar index is -0.63 (nonbank share) and 0.38 (bank share). 
Figure 2: Syndication timeline

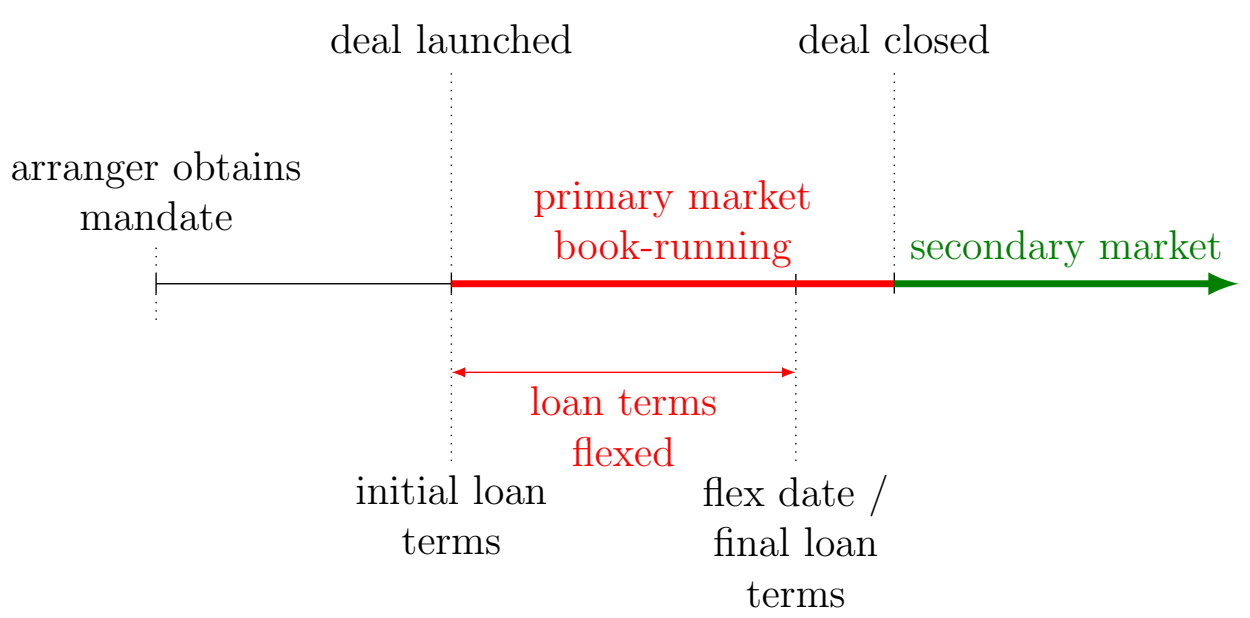

Timeline for the leveraged term loan syndication process based on Bruche, Malherbe, and Meisenzahl (forthcoming). 
Figure 3: High Yield Spread and the Dollar Index

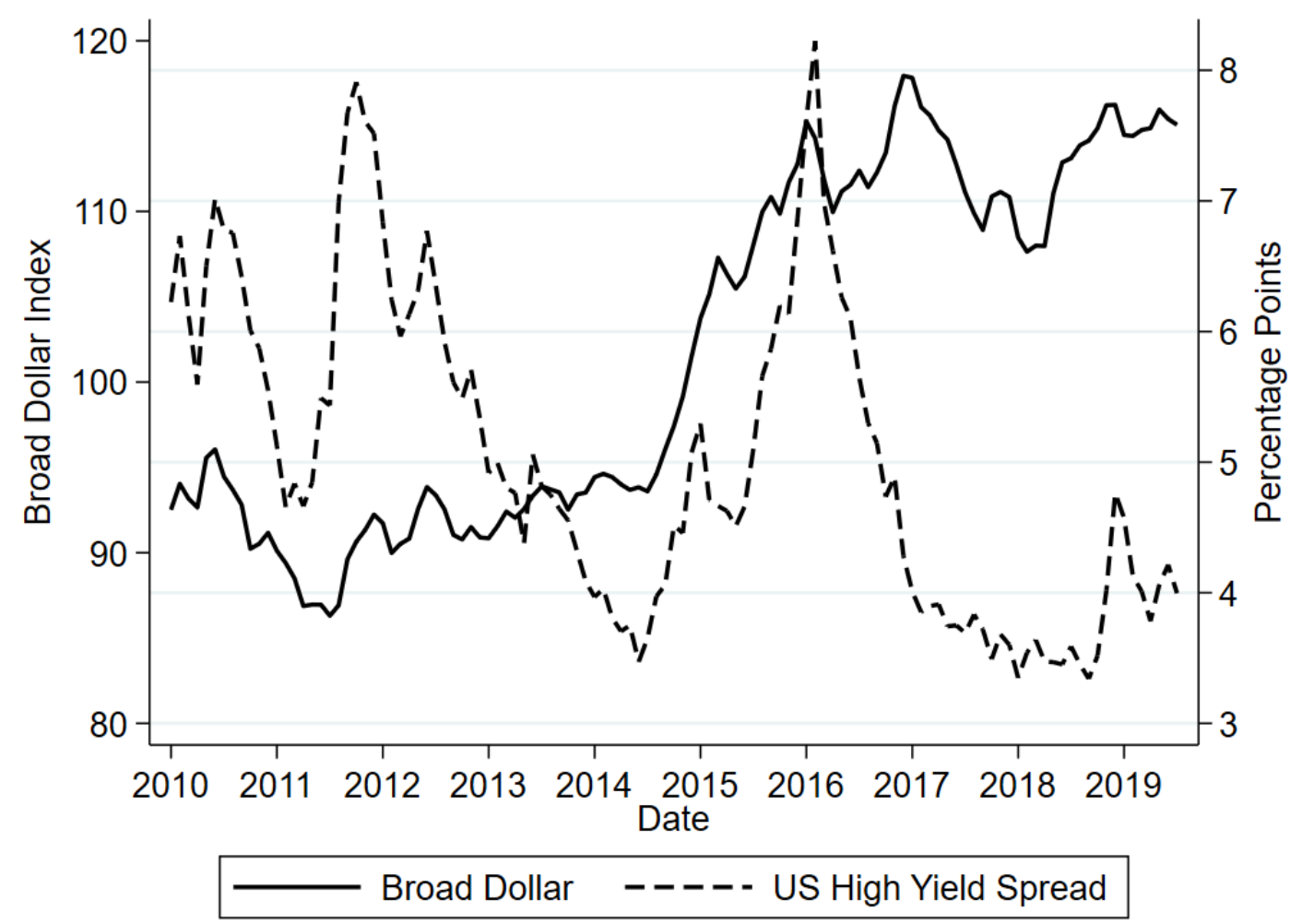

Note: The figure shows the broad dollar index and the US high yield spread from 2009 to 2019. The high yield spread is the Master II Option-Adjusted Spread from FRED. 
Figure 4: Total Number of Loans and Loan Amounts

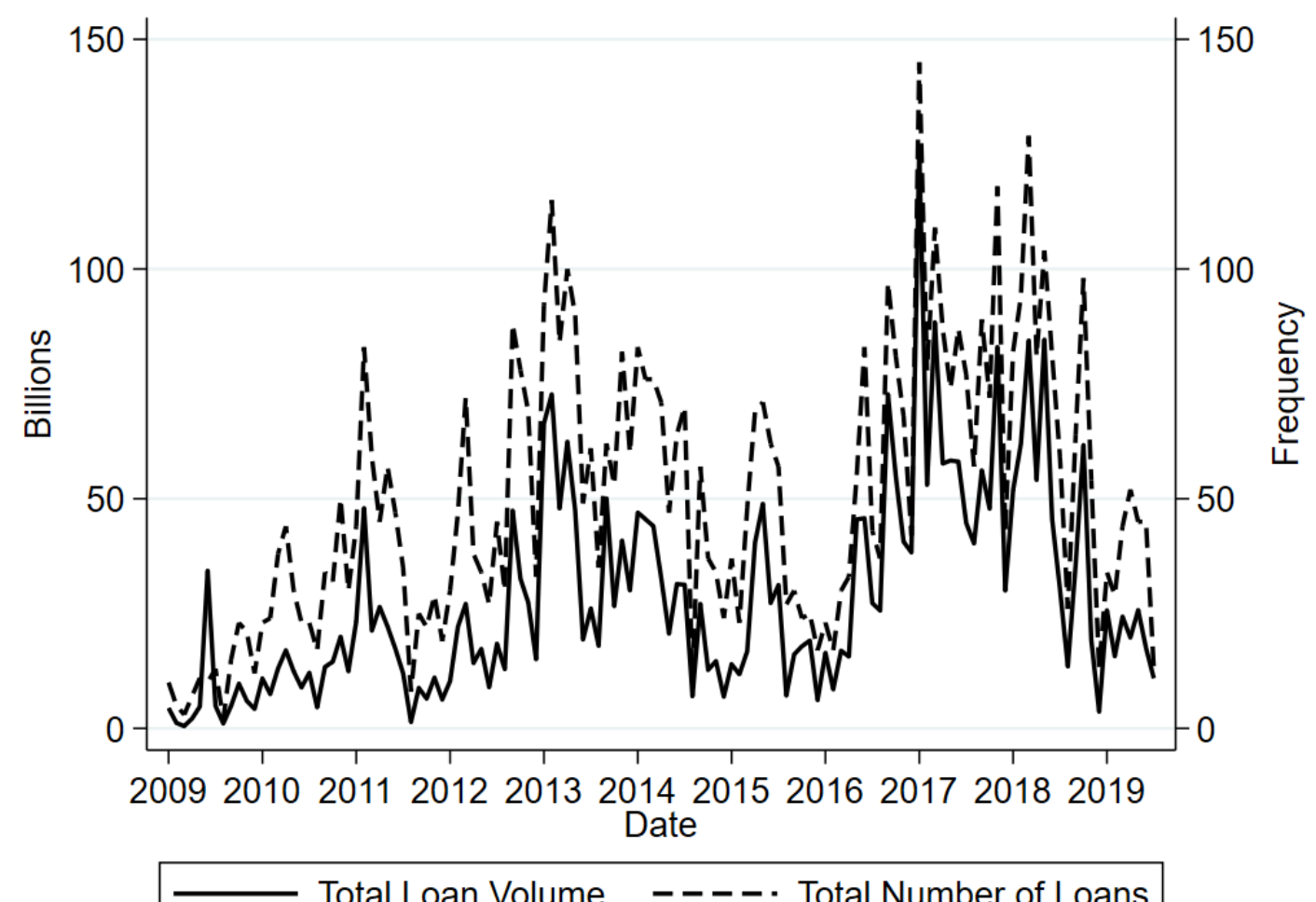

Note: The figure shows the total loan volume and the total number of loans on a monthly basis, from 2009 to 2019. The total loan volume is represented in USD billions, and the total number of loans is a simple frequency count. The figure uses US-borrowers only. Sources: S\&P Capital IQ Leveraged Loan Commentary Data (LCD) and Dealscan. 
Figure 5: Share of Loans with Spread and with Amount Flexes
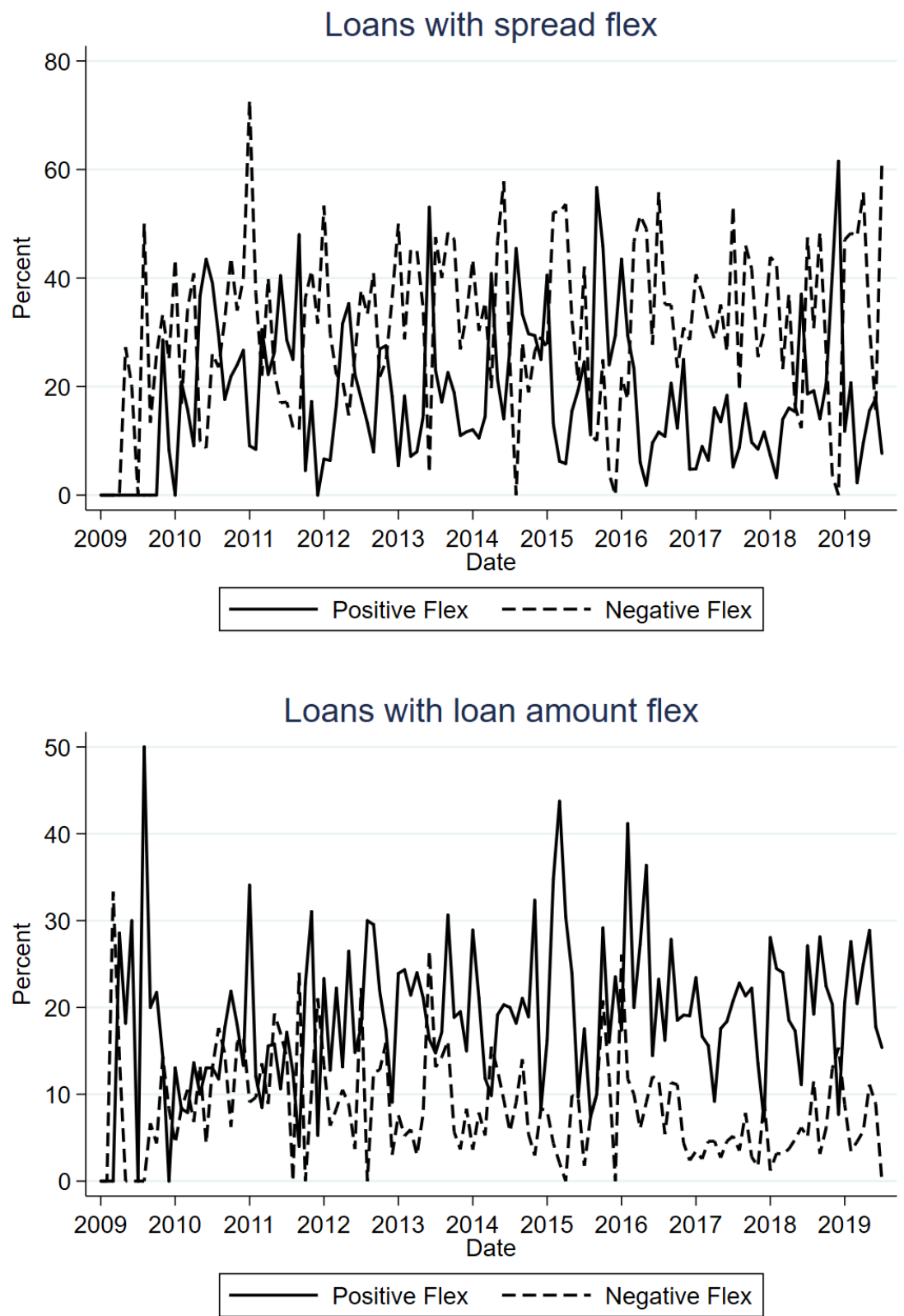

Note: This figure shows the share of total loans that have a positive or negative flex, on a monthly basis from 2009 to 2019. The top panel shows flexes in the spread. The bottom panel shows flexes in the loan amount. The figure uses US-borrowers only. Sources: LCD and Dealscan. 
Figure 6: Effective Spread Flex and Changes in the Dollar Index

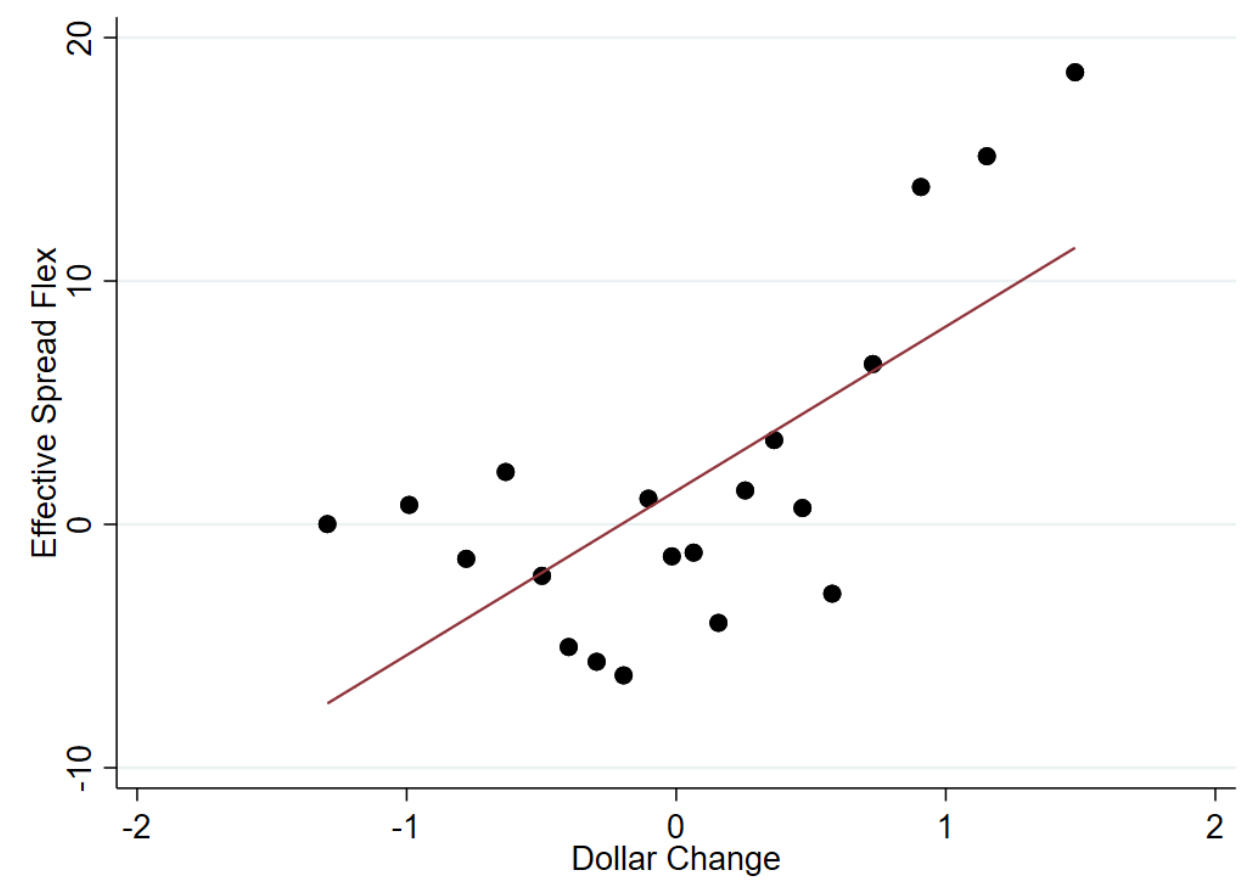

Note: The figure shows the effective spread flex plotted against the change in the broad dollar index. The dollar change is the change in the dollar from launch to flex date. The scatter plot was created by grouping changes in the dollar into equal-sized bins, computing the mean of the dollar and the effective spread flex in each bin, and then plotting the points. A line of best fit is also included. The figure excludes outliers and uses only US-borrowers. Loan-specific variables are used as controls. Source: Authors calculations based on LCD data. 


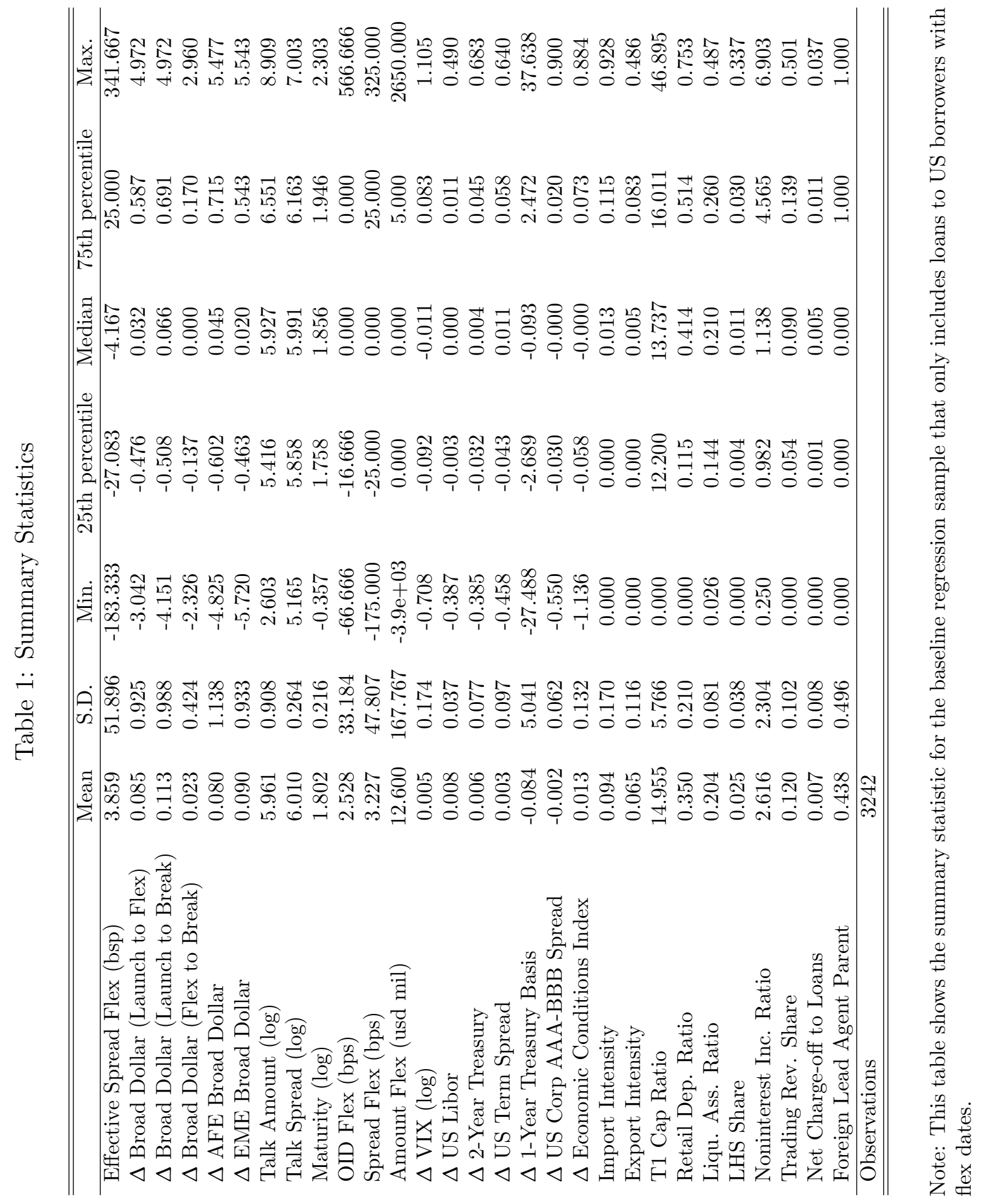


Table 2: Dollar and Effective Spread Flex Incidences

\begin{tabular}{lcccc}
\hline \hline & $(1)$ & $(2)$ & $(3)$ & $(4)$ \\
& Positive Eff. & Negative Eff. & Positive with & Negative with \\
& Spread Flex & Spread Flex & Flex Date & Flex Date \\
\hline \multirow{3}{*}{ B Broad Dollar } & & & & \\
& $0.168^{* * *}$ & $-0.182^{* * *}$ & $0.271^{* * *}$ & $-0.266^{* * *}$ \\
Talk Spread $(\log )$ & $(0.0316)$ & $(0.0387)$ & $(0.0440)$ & $(0.0446)$ \\
& -0.144 & $-2.351^{* * *}$ & $2.038^{* * *}$ & $-2.207^{* * *}$ \\
Talk Amount $(\log )$ & $(0.103)$ & $(0.147)$ & $(0.186)$ & $(0.192)$ \\
& -0.0449 & $-0.459^{* * *}$ & $0.341^{* * *}$ & $-0.349^{* * *}$ \\
Years to Maturity $(\log )$ & $(0.0308)$ & $(0.0424)$ & $(0.0527)$ & $(0.0537)$ \\
& $-1.431^{* * *}$ & $-1.285^{* * *}$ & 0.0105 & -0.111 \\
Sponsored & $(0.185)$ & $(0.199)$ & $(0.199)$ & $(0.206)$ \\
& 0.0774 & $-0.174^{* *}$ & 0.119 & $-0.214^{* *}$ \\
Rated & $(0.0615)$ & $(0.0829)$ & $(0.0918)$ & $(0.0940)$ \\
& -0.0882 & $-0.375^{* * *}$ & $0.254^{*}$ & $-0.235^{*}$ \\
Cov-Lite & $(0.101)$ & $(0.121)$ & $(0.140)$ & $(0.142)$ \\
& $-0.198^{* * *}$ & $0.209^{* * *}$ & $-0.248^{* * *}$ & $0.286^{* * *}$ \\
Middle Market & $(0.0632)$ & $(0.0794)$ & $(0.0878)$ & $(0.0891)$ \\
& $0.367^{* * *}$ & $-0.592^{* * *}$ & $0.740^{* * *}$ & $-0.722^{* * *}$ \\
& $(0.0933)$ & $(0.104)$ & $(0.123)$ & $(0.124)$ \\
\hline Observations & 6249 & 6249 & 3235 & 3235 \\
Pseudo $R^{2}$ & 0.030 & 0.088 & 0.073 & 0.082 \\
\hline \hline
\end{tabular}

Note: This table shows the effect of the change in the broad dollar index on the probability of observing an effective spread flex of loans to U.S. borrowers. In this table, the change in the broad dollar is calculated as the change from launch date to launch date plus 12 days, which is the average length of origination in our sample. The table shows the results of a logit regression, testing separately for the occurrence of positive and negative flexes. The dependent variable is the effective spread flex in basis points, calculated as the spread flex plus OID flex divided by four. Column 1 and column 2 include all loans. Column 3 and column 4 restrict the sample to only loans that have a flex date. All loan controls are taken from LCD and are described in Appendix A. The sample period is from 2009 to 2019. Robust standard errors are in parentheses. ${ }^{*}, * *$, and $* * *$ denote significance at the $10 \%, 5 \%$, and $1 \%$ level. 
Table 3: Dollar and Effective Spread Flex

\begin{tabular}{|c|c|c|c|c|c|c|}
\hline & \multicolumn{3}{|c|}{ All Loans } & \multicolumn{3}{|c|}{ Flex Only } \\
\hline & $(1)$ & $(2)$ & $(3)$ & $(4)$ & $(5)$ & $(6)$ \\
\hline$\Delta$ Broad Dollar & $\begin{array}{c}2.449^{* * *} * \\
(0.571)\end{array}$ & $\begin{array}{c}2.618^{* * *} \\
(0.576)\end{array}$ & $\begin{array}{c}2.449^{* * *} \\
(0.581)\end{array}$ & $\begin{array}{c}6.476^{* * *} \\
(1.250)\end{array}$ & $\begin{array}{c}6.496^{* * *} \\
(1.188)\end{array}$ & $\begin{array}{c}6.381^{* * *} \\
(1.184)\end{array}$ \\
\hline Talk Amount(log) & & $\begin{array}{c}1.207^{* * *} * \\
(0.437)\end{array}$ & $\begin{array}{l}0.845^{*} \\
(0.513)\end{array}$ & & $\begin{array}{c}1.170 \\
(0.965)\end{array}$ & $\begin{array}{c}0.804 \\
(1.065)\end{array}$ \\
\hline Talk Spread (log) & & $\begin{array}{c}13.46^{* * *} \\
(2.128)\end{array}$ & $\begin{array}{c}11.37^{* * *} \\
(2.376)\end{array}$ & & $\begin{array}{c}31.39 * * * \\
(4.567)\end{array}$ & $\begin{array}{c}25.66^{* * *} \\
(4.803)\end{array}$ \\
\hline Years to Maturity (log) & & $\begin{array}{l}-1.530 \\
(1.590)\end{array}$ & $\begin{array}{c}-7.722^{* * *} \\
(2.422)\end{array}$ & & $\begin{array}{l}-7.337 \\
(5.073)\end{array}$ & $\begin{array}{c}-16.89 * * * \\
(5.855)\end{array}$ \\
\hline Sponsored & & $\begin{array}{c}0.976 \\
(1.109)\end{array}$ & $\begin{array}{c}1.373 \\
(1.203)\end{array}$ & & $\begin{array}{c}0.933 \\
(2.155)\end{array}$ & $\begin{array}{c}2.550 \\
(2.362)\end{array}$ \\
\hline Rated & & $\begin{array}{c}4.101^{* *} \\
(1.825)\end{array}$ & $\begin{array}{c}2.718 \\
(2.263)\end{array}$ & & $\begin{array}{c}5.589 \\
(3.894)\end{array}$ & $\begin{array}{c}3.576 \\
(4.602)\end{array}$ \\
\hline Cov-Lite & & $\begin{array}{c}-4.687^{* * * *} \\
(1.041)\end{array}$ & $\begin{array}{c}-4.252^{* * *} \\
(1.143)\end{array}$ & & $\begin{array}{c}-7.682^{* * *} \\
(1.978)\end{array}$ & $\begin{array}{c}-7.237^{* * *} * \\
(2.118)\end{array}$ \\
\hline Middle Market & & $\begin{array}{c}8.265^{* * *} \\
(1.824)\end{array}$ & $\begin{array}{c}9.320^{* * *} \\
(2.063)\end{array}$ & & $\begin{array}{c}14.57^{* * *} * \\
(3.409)\end{array}$ & $\begin{array}{c}17.42^{* * *} \\
(3.807)\end{array}$ \\
\hline Industry & No & No & Yes & No & No & Yes \\
\hline Purpose & No & No & Yes & No & No & Yes \\
\hline Lead Agent & No & No & Yes & No & No & Yes \\
\hline Observations & 6379 & 6249 & 6190 & 3242 & 3235 & 3224 \\
\hline$R^{2}$ & 0.003 & 0.031 & 0.059 & 0.013 & 0.070 & 0.116 \\
\hline
\end{tabular}

Note: This table shows the effect of the change in the broad dollar index on the effective spread flex of loans to U.S. borrowers. Columns 1-3 include all loans. The dollar change is calculated as change over the first 12 days after the launch date. Columns 4-6 include only loans that have OID flex and/or spread flex. The dollar change is calculated as change between launch date and flex date. The dependent variable is the effective spread flex in basis points, calculated as the spread flex plus OID flex divided by four. All loan controls are taken from LCD and described in Appendix A. The sample period is from 2009 to 2019. Robust standard errors are in parentheses. ${ }^{*}, * *$, and ${ }^{* * *}$ denote significance at the $10 \%, 5 \%$, and $1 \%$ level. 
Table 4: Macroeconomic Controls

\begin{tabular}{lcccc}
\hline \hline & $(1)$ & $(2)$ & $(3)$ & $(4)$ \\
\hline & & & & \\
& $7.033^{* * *}$ & $5.471^{* * *}$ & $5.458^{* * *}$ & $3.392^{* * *}$ \\
Talk Amount(log) & $(1.218)$ & $(1.233)$ & $(1.231)$ & $(1.263)$ \\
& 1.248 & 1.238 & 0.869 & 1.262 \\
Talk Spread (log) & $(0.960)$ & $(0.955)$ & $(1.059)$ & $(1.046)$ \\
& $31.52^{* * *}$ & $33.05^{* * *}$ & $28.08^{* * *}$ & $27.99^{* * *}$ \\
Years to Maturity (log) & $(4.602)$ & $(4.596)$ & $(4.828)$ & $(4.897)$ \\
& -7.949 & -8.025 & $-17.23^{* * *}$ & $-19.05^{* * *}$ \\
Sponsored & $(5.118)$ & $(5.154)$ & $(5.956)$ & $(6.039)$ \\
& 1.048 & 0.607 & 2.465 & 3.683 \\
Rated & $(2.156)$ & $(2.147)$ & $(2.348)$ & $(2.341)$ \\
& 5.882 & 5.671 & 3.898 & 1.754 \\
Cov-Lite & $(3.914)$ & $(3.906)$ & $(4.624)$ & $(4.573)$ \\
& $-7.938^{* * *}$ & $-7.843^{* * *}$ & $-7.075^{* * *}$ & $-9.328^{* * *}$ \\
Middle Market & $(1.967)$ & $(1.953)$ & $(2.089)$ & $(2.232)$ \\
& $14.56^{* * *}$ & $14.10^{* * *}$ & $17.10^{* * *}$ & $17.69^{* * *}$ \\
$\Delta$ VIX (log) & $(3.377)$ & $(3.372)$ & $(3.791)$ & $(3.849)$ \\
& $-17.55^{* * *}$ & $-21.77^{* * *}$ & $-21.73^{* * *}$ & $-19.09^{* * *}$ \\
$\Delta$ US Corp AAA-BBB Spread & $(5.517)$ & $(5.499)$ & $(5.509)$ & $(5.556)$ \\
& & $94.42^{* * *}$ & $88.38^{* * *}$ & $53.68^{* *}$ \\
$\Delta$ US Term Spread & & $(20.78)$ & $(20.48)$ & $(21.50)$ \\
& 17.58 & 9.687 & 12.54 & 7.988 \\
$\Delta$ Economic Conditions Index & $(12.17)$ & $(12.11)$ & $(11.50)$ & $(12.28)$ \\
& & -12.82 & -12.91 & 1.233 \\
$\Delta$ US Libor & & $(9.464)$ & $(9.345)$ & $(9.725)$ \\
& $\left(23.93^{* * *}\right.$ & $52.19^{*}$ & $54.98^{*}$ & 7.973 \\
$\Delta$ 2-Year Treasury & $(28.22)$ & $(29.06)$ & $(28.45)$ & $(36.89)$ \\
Industry & $-38.87^{* *}$ & -22.15 & -26.02 & -12.57 \\
Purpose & $(15.89)$ & $(16.10)$ & $(16.29)$ & $(16.30)$ \\
Lead Agent Near-Quarter & No & No & Yes & Yes \\
\hline Observations & No & No & Yes & Yes \\
$R^{2}$ & No & No & No & Yes \\
\hline \hline
\end{tabular}

Note: This table shows the effect of the change in the broad dollar index on the effective spread flex of loans to U.S. borrowers, using macroeconomic variables as controls. The dependent variable is the effective spread flex in basis points, calculated as the spread flex plus OID flex divided by four. This table includes only loans that have a flex date. Loan controls are taken from LCD. All variables are described in Appendix A. The sample period is from 2009 to 2019 . Robust standard errors are in parentheses. *,**, and ${ }^{* * *}$ denote significance at the $10 \%, 5 \%$, and $1 \%$ level. 


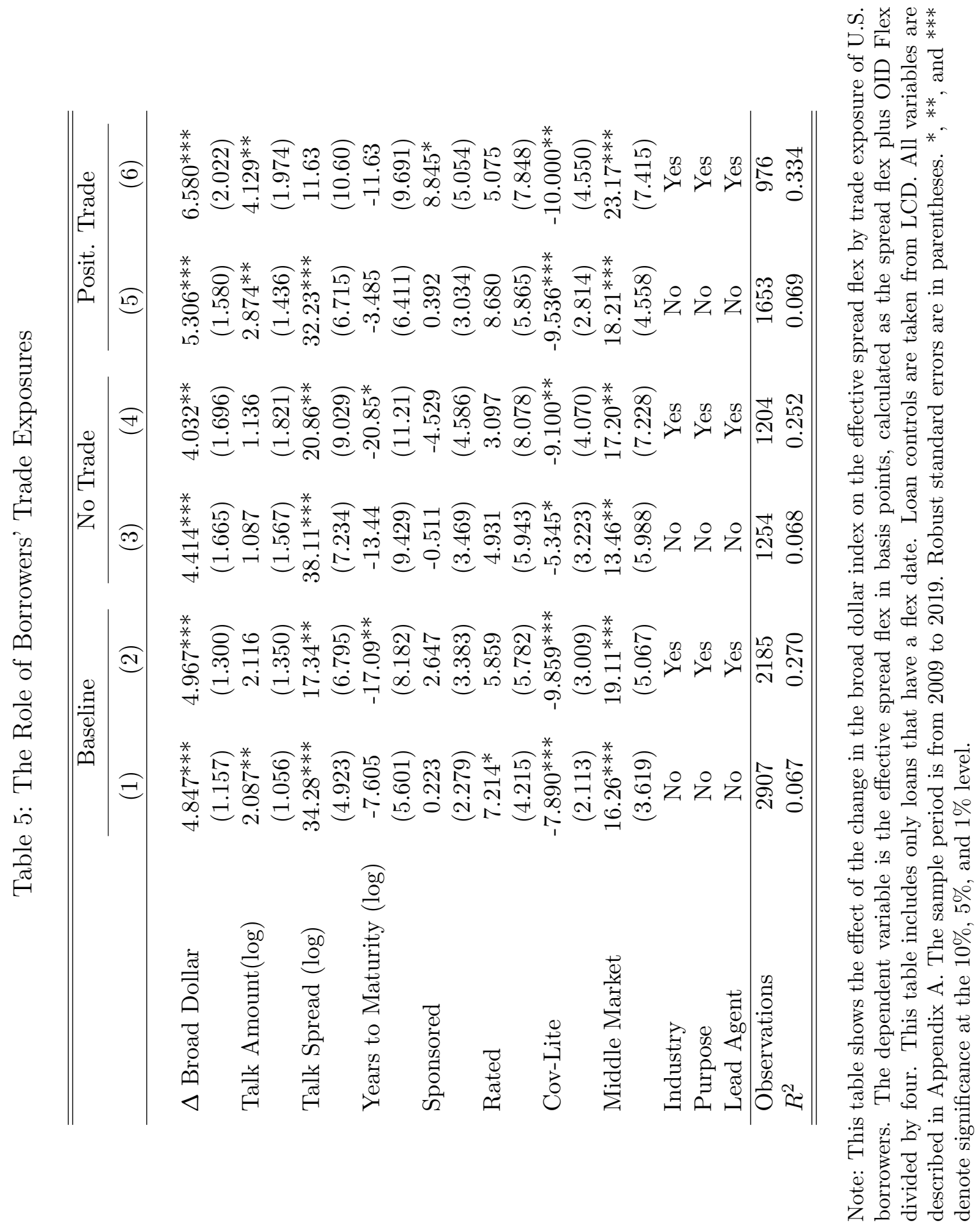


Table 6: The Role of Lead Agent Characteristics

\begin{tabular}{|c|c|c|c|c|c|c|c|}
\hline & \multicolumn{7}{|c|}{ Flex Only } \\
\hline & $(1)$ & $(2)$ & (3) & (4) & $(5)$ & (6) & (7) \\
\hline$\Delta$ Broad Dollar (Launch to Flex) & $\begin{array}{c}5.859 \\
(4.254)\end{array}$ & $\begin{array}{c}6.720^{* * *} \\
(2.541)\end{array}$ & $\begin{array}{c}9.200^{* * *} \\
(3.293)\end{array}$ & $\begin{array}{c}6.550^{* * *} \\
(1.837)\end{array}$ & $\begin{array}{c}6.668^{* * * *} \\
(2.205)\end{array}$ & $\begin{array}{l}5.384^{* *} \\
(2.199)\end{array}$ & $\begin{array}{c}5.679^{* * * *} \\
(1.754)\end{array}$ \\
\hline Talk Amount(log) & $\begin{array}{c}0.953 \\
(1.204)\end{array}$ & $\begin{array}{c}0.996 \\
(1.217)\end{array}$ & $\begin{array}{c}0.867 \\
(1.209)\end{array}$ & $\begin{array}{c}0.928 \\
(1.210)\end{array}$ & $\begin{array}{c}1.253 \\
(1.178)\end{array}$ & $\begin{array}{c}0.837 \\
(1.212)\end{array}$ & $\begin{array}{c}0.912 \\
(1.210)\end{array}$ \\
\hline Talk Spread (log) & $\begin{array}{c}31.27^{* * * *} \\
(5.644)\end{array}$ & $\begin{array}{c}31.30^{* * * *} \\
(5.732)\end{array}$ & $\begin{array}{c}31.44^{* * * *} \\
(5.720)\end{array}$ & $\begin{array}{c}30.91^{* * * *} \\
(5.753)\end{array}$ & $\begin{array}{c}32.25^{\text {**** }} \\
(5.642)\end{array}$ & $\begin{array}{c}30.37^{* * * *} \\
(5.716)\end{array}$ & $\begin{array}{c}32.37^{* * * *} \\
(5.831)\end{array}$ \\
\hline Years to Maturity (log) & $\begin{array}{c}-19.20^{* *} \\
(7.559)\end{array}$ & $\begin{array}{c}-19.26^{* *} \\
(7.515)\end{array}$ & $\begin{array}{c}-19.48^{* * *} \\
(7.504)\end{array}$ & $\begin{array}{c}-19.22^{* *} \\
(7.543)\end{array}$ & $\begin{array}{c}-19.60^{* * *} \\
(7.556)\end{array}$ & $\begin{array}{c}-19.22^{* *} \\
(7.476)\end{array}$ & $\begin{array}{c}-19.39^{* *} \\
(7.506)\end{array}$ \\
\hline Sponsored & $\begin{array}{c}2.216 \\
(2.601)\end{array}$ & $\begin{array}{c}2.091 \\
(2.601)\end{array}$ & $\begin{array}{c}2.293 \\
(2.597)\end{array}$ & $\begin{array}{c}2.193 \\
(2.606)\end{array}$ & $\begin{array}{l}2.062 \\
(2.594)\end{array}$ & $\begin{array}{c}2.104 \\
(2.594)\end{array}$ & $\begin{array}{c}2.501 \\
(2.571)\end{array}$ \\
\hline Rated & $\begin{array}{l}9.485^{*} \\
(5.283)\end{array}$ & $\begin{array}{l}9.763^{*} \\
(5.437)\end{array}$ & $\begin{array}{l}9.488^{*} \\
(5.324)\end{array}$ & $\begin{array}{l}9.552^{*} \\
(5.282)\end{array}$ & $\begin{array}{l}9.497^{*} \\
(5.306)\end{array}$ & $\begin{array}{l}9.831^{*} \\
(5.324)\end{array}$ & $\begin{array}{l}10.23^{*} \\
(5.422)\end{array}$ \\
\hline Cov-Lite & $\begin{array}{l}-4.801^{*} \\
(2.705)\end{array}$ & $\begin{array}{l}-5.104^{*} \\
(2.751)\end{array}$ & $\begin{array}{c}-5.554^{* *} \\
(2.685)\end{array}$ & $\begin{array}{l}-4.400^{*} \\
(2.643)\end{array}$ & $\begin{array}{l}-5.239^{*} \\
(2.679)\end{array}$ & $\begin{array}{l}-3.805 \\
(2.672)\end{array}$ & $\begin{array}{c}-7.260^{* *} \\
(2.856)\end{array}$ \\
\hline Middle Market & $\begin{array}{c}21.64^{* * *} \\
(5.825)\end{array}$ & $\begin{array}{c}22.27^{* * *} \\
(5.925)\end{array}$ & $\begin{array}{c}21.58^{* * *} \\
(5.850)\end{array}$ & $\begin{array}{c}21.72^{* * *} * \\
(5.847)\end{array}$ & $\begin{array}{c}21.56^{* * *} \\
(5.838)\end{array}$ & $\begin{array}{c}21.67^{* * * *} \\
(5.848)\end{array}$ & $\begin{array}{c}21.45^{* * *} * \\
(5.859)\end{array}$ \\
\hline$\Delta$ Dollar X T1 Cap Ratio & $\begin{array}{l}0.0312 \\
(0.256)\end{array}$ & & & & & & \\
\hline T1 Cap Ratio & $\begin{array}{l}0.256 \\
(0.252)\end{array}$ & & & & & & \\
\hline$\Delta$ Dollar X Retail Dep. Ratio & & $\begin{array}{l}-1.412 \\
(6.107)\end{array}$ & & & & & \\
\hline Retail Dep. Ratio & & $\begin{array}{c}14.41 \\
(15.85)\end{array}$ & & & & & \\
\hline$\Delta$ Dollar X Liqu. Ass. Ratio & & & $\begin{array}{l}-13.84 \\
(15.52)\end{array}$ & & & & \\
\hline Liqu. Ass. Ratio & & & $\begin{array}{l}54.15^{*} \\
(30.64)\end{array}$ & & & & \\
\hline$\Delta$ Dollar X LHS Share & & & & $\begin{array}{l}-7.537 \\
(33.24)\end{array}$ & & & \\
\hline LHS Share & & & & $\begin{array}{l}-2.676 \\
(65.15)\end{array}$ & & & \\
\hline$\Delta$ Dollar X Noninterest Inc. Ratio & & & & & $\begin{array}{l}-0.188 \\
(0.557)\end{array}$ & & \\
\hline Noninterest Inc. Ratio & & & & & $\begin{array}{l}3.283^{* *} \\
(1.430)\end{array}$ & & \\
\hline$\Delta$ Dollar X Trading Rev. Share & & & & & & $\begin{array}{c}8.461 \\
(12.97)\end{array}$ & \\
\hline Trading Rev. Share & & & & & & $\begin{array}{c}67.08 \\
(47.88)\end{array}$ & \\
\hline$\Delta$ Dollar X Net Charge-off to Loans & & & & & & & $\begin{array}{c}65.65 \\
(191.3)\end{array}$ \\
\hline Net Charge-off to Loans & & & & & & & $\begin{array}{c}-712.8^{* * *} \\
(243.4)\end{array}$ \\
\hline Industry & Yes & Yes & Yes & Yes & Yes & Yes & Yes \\
\hline Purpose & Yes & Yes & Yes & Yes & Yes & Yes & Yes \\
\hline Lead Agent & Yes & Yes & Yes & Yes & Yes & Yes & Yes \\
\hline Observations & 2066 & 2059 & 2066 & 2066 & 2066 & 2066 & 2066 \\
\hline$R^{2}$ & 0.122 & 0.122 & 0.124 & 0.121 & 0.125 & 0.123 & 0.127 \\
\hline
\end{tabular}

Note: This table shows that the effect of dollar movements on loan prices does not depend on lead agent characteristics. The regressions shown are parallel to that in column 5 of table 3. The dependent variable is the effective spread flex in basis points, calculated as the spread flex plus OID Flex divided by four. Only loans that have OID flex and/or spread flex are included in the sample. The dollar change is calculated as the change in the broad dollar index between launch date and flex date. Loan controls are described in Appendix A. The sample period is from 2009 to 2019. Standard errors are clustered by lead agent $\mathrm{X}$ year-quarter and are in parentheses. ${ }^{*}, * *$, and ${ }^{* * *}$ denote significance at the $10 \%, 5 \%$, and $1 \%$ level. 
Table 7: Foreign Lead Agents

\begin{tabular}{|c|c|c|c|c|}
\hline & \multicolumn{2}{|c|}{ All Loans } & \multicolumn{2}{|c|}{ Flex Only } \\
\hline & $(1)$ & $(2)$ & $(3)$ & $(4)$ \\
\hline$\Delta$ Broad Dollar & $\begin{array}{c}2.566^{* * *} \\
(0.740)\end{array}$ & $\begin{array}{c}2.536^{* * *} \\
(0.734)\end{array}$ & $\begin{array}{c}6.635^{* * *} \\
(1.446)\end{array}$ & $\begin{array}{c}6.676^{* * *} \\
(1.442)\end{array}$ \\
\hline Talk Amount(log) & $\begin{array}{l}1.025^{* *} \\
(0.433)\end{array}$ & $\begin{array}{c}0.455 \\
(0.508)\end{array}$ & $\begin{array}{c}0.988 \\
(0.940)\end{array}$ & $\begin{array}{c}0.279 \\
(1.050)\end{array}$ \\
\hline Talk Spread (log) & $\begin{array}{c}12.99^{* * *} * \\
(2.310)\end{array}$ & $\begin{array}{c}10.32^{* * * *} \\
(2.506)\end{array}$ & $\begin{array}{c}29.51^{* * *} \\
(4.741)\end{array}$ & $\begin{array}{c}23.24^{* * *} \\
(5.017)\end{array}$ \\
\hline Years to Maturity (log) & $\begin{array}{l}-2.681 \\
(2.009)\end{array}$ & $\begin{array}{c}-8.643^{* * *} \\
(2.628)\end{array}$ & $\begin{array}{l}-6.993 \\
(5.204)\end{array}$ & $\begin{array}{c}-17.85^{* * *} \\
(6.098)\end{array}$ \\
\hline Sponsored & $\begin{array}{c}1.238 \\
(1.186)\end{array}$ & $\begin{array}{c}1.622 \\
(1.251)\end{array}$ & $\begin{array}{c}1.909 \\
(2.244)\end{array}$ & $\begin{array}{c}2.918 \\
(2.447)\end{array}$ \\
\hline Rated & $\begin{array}{c}4.117^{* *} \\
(1.963)\end{array}$ & $\begin{array}{c}3.189 \\
(2.387)\end{array}$ & $\begin{array}{l}6.802^{*} \\
(3.972)\end{array}$ & $\begin{array}{c}5.391 \\
(4.742)\end{array}$ \\
\hline Cov-Lite & $\begin{array}{c}-4.311^{* * *} \\
(1.110)\end{array}$ & $\begin{array}{c}-3.865^{* * *} \\
(1.198)\end{array}$ & $\begin{array}{c}-7.364^{* * *} \\
(2.064)\end{array}$ & $\begin{array}{c}-6.860^{* * * *} \\
(2.199)\end{array}$ \\
\hline Middle Market & $\begin{array}{c}8.143^{* * *} \\
(1.991)\end{array}$ & $\begin{array}{c}9.433^{* * * *} \\
(2.261)\end{array}$ & $\begin{array}{c}14.42^{* * * *} \\
(3.634)\end{array}$ & $\begin{array}{c}17.79^{* * *} \\
(4.104)\end{array}$ \\
\hline Foreign Lead Agent Parent & $\begin{array}{l}-1.161 \\
(1.053)\end{array}$ & & $\begin{array}{c}-3.161^{*} \\
(1.921)\end{array}$ & \\
\hline$\Delta$ Dollar (Lt12) X Foreign Lead Agent Parent & $\begin{array}{l}0.0771 \\
(1.269)\end{array}$ & $\begin{array}{l}-0.217 \\
(1.239)\end{array}$ & & \\
\hline$\Delta$ Dollar (Ltf) X Foreign Lead Agent Parent & & & $\begin{array}{l}-0.401 \\
(2.634)\end{array}$ & $\begin{array}{l}-0.614 \\
(2.538)\end{array}$ \\
\hline Industry & No & Yes & No & Yes \\
\hline Purpose & No & Yes & No & Yes \\
\hline Lead Agent & No & Yes & No & Yes \\
\hline Observations & 5577 & 5576 & 2951 & 2950 \\
\hline$R^{2}$ & 0.028 & 0.054 & 0.064 & 0.107 \\
\hline
\end{tabular}

Note: This table shows that the effect dollar movements on loan prices does not differ between U.S. and foreign-owned lead agents. The dependent variable is the effective spread flex in basis points, calculated as the spread flex plus OID Flex divided by four. Columns 1-2 include all loans and the dollar change is calculated as the change over the first 12 days after the launch date. Columns 3-4 include only loans that have OID flex and/or spread flex. Here, the dollar change is calculated as the change in the broad dollar index between launch date and flex date. Foreign Lead Agent Parent is a dummy variable that takes the value of 1 if the lead agent is owned by a foreign parent. Other loan controls are described in Appendix A. The sample period is from 2009 to 2019. Robust standard errors are in parentheses. $*, * *$, and $* * *$ denote significance at the $10 \%, 5 \%$, and $1 \%$ level. 
Table 8: Loan Amount Flex

\begin{tabular}{|c|c|c|c|c|}
\hline & $\begin{array}{c}(1) \\
\text { All Loans } \\
\end{array}$ & $\begin{array}{c}\text { Loans with Amount Flex } \\
\text { Le }\end{array}$ & $\begin{array}{c}(3) \\
\text { Positive Amount Flex } \\
\end{array}$ & $\begin{array}{c}\text { (4) } \\
\text { Negative Amount Flex }\end{array}$ \\
\hline$\Delta$ Broad Dollar & $\begin{array}{c}-0.00367 \\
(0.00288)\end{array}$ & $\begin{array}{c}-0.0222^{* *} \\
(0.00872)\end{array}$ & $\begin{array}{c}-0.117^{* *} \\
(0.0552)\end{array}$ & $\begin{array}{c}0.0231 \\
(0.0399)\end{array}$ \\
\hline Talk Spread $(\log )$ & $\begin{array}{l}-0.00306 \\
(0.0104)\end{array}$ & $\begin{array}{c}-0.0994^{* *} \\
(0.0415)\end{array}$ & $\begin{array}{c}-0.813^{* * *} \\
(0.165)\end{array}$ & $\begin{array}{c}-1.034^{* * *} \\
(0.126)\end{array}$ \\
\hline Years to Maturity $(\log )$ & $\begin{array}{l}0.0101 \\
(0.0120)\end{array}$ & $\begin{array}{l}-0.0717 \\
(0.0541)\end{array}$ & $\begin{array}{c}-1.010^{* * *} \\
(0.216)\end{array}$ & $\begin{array}{c}-1.595^{* * *} \\
(0.193)\end{array}$ \\
\hline Sponsored & $\begin{array}{l}-0.00274 \\
(0.00647)\end{array}$ & $\begin{array}{c}0.0128 \\
(0.0232)\end{array}$ & $\begin{array}{c}0.556^{* * *} \\
(0.102)\end{array}$ & $\begin{array}{l}-0.143^{*} \\
(0.0742)\end{array}$ \\
\hline Rated & $\begin{array}{l}0.00485 \\
(0.00548)\end{array}$ & $\begin{array}{c}0.0186 \\
(0.0231)\end{array}$ & $\begin{array}{c}-0.289^{*} \\
(0.163)\end{array}$ & $\begin{array}{c}-0.289^{* *} \\
(0.124)\end{array}$ \\
\hline Cov-Lite & $\begin{array}{l}0.0143^{* *} \\
(0.00640)\end{array}$ & $\begin{array}{c}0.0435^{* *} \\
(0.0216)\end{array}$ & $\begin{array}{c}0.282^{* * * *} \\
(0.108)\end{array}$ & $\begin{array}{c}-0.267^{* * *} \\
(0.0752)\end{array}$ \\
\hline Middle Market & $\begin{array}{c}-0.0169^{* * *} \\
(0.00483)\end{array}$ & $\begin{array}{c}-0.0500^{* *} \\
(0.0206)\end{array}$ & $\begin{array}{l}0.0206 \\
(0.142)\end{array}$ & $\begin{array}{c}0.584^{* * * *} \\
(0.113)\end{array}$ \\
\hline$\Delta$ VIX $(\log )$ & $\begin{array}{c}0.0295^{* *} \\
(0.0137)\end{array}$ & $\begin{array}{l}0.120^{* *} \\
(0.0497)\end{array}$ & $\begin{array}{l}0.374 \\
(0.285)\end{array}$ & $\begin{array}{l}-0.342^{*} \\
(0.190)\end{array}$ \\
\hline$\Delta$ US Corp AAA-BBB Spread & $\begin{array}{c}-0.0907^{* *} \\
(0.0402)\end{array}$ & $\begin{array}{l}-0.192 \\
(0.117)\end{array}$ & $\begin{array}{l}-1.612^{*} \\
(0.877)\end{array}$ & $\begin{array}{c}1.870^{* * *} \\
(0.533)\end{array}$ \\
\hline$\Delta$ US Term Spread & $\begin{array}{c}-0.0110 \\
(0.0288)\end{array}$ & $\begin{array}{l}-0.0846 \\
(0.0828)\end{array}$ & $\begin{array}{c}0.265 \\
(0.581)\end{array}$ & $\begin{array}{c}0.442 \\
(0.396)\end{array}$ \\
\hline$\Delta$ Economic Conditions Index & $\begin{array}{l}-0.0155 \\
(0.0260)\end{array}$ & $\begin{array}{l}-0.0805 \\
(0.0640)\end{array}$ & $\begin{array}{l}-0.220 \\
(0.406)\end{array}$ & $\begin{array}{l}-0.420 \\
(0.282)\end{array}$ \\
\hline$\Delta$ US Libor & $\begin{array}{l}-0.0401 \\
(0.0680)\end{array}$ & $\begin{array}{l}-0.0251 \\
(0.166)\end{array}$ & $\begin{array}{c}4.796^{* * *} \\
(1.736)\end{array}$ & $\begin{array}{l}-0.777 \\
(1.078)\end{array}$ \\
\hline$\Delta$ 2-Year Treasury & $\begin{array}{l}0.104^{* *} \\
(0.0476)\end{array}$ & $\begin{array}{l}0.254^{*} \\
(0.143)\end{array}$ & $\begin{array}{l}0.402 \\
(0.846)\end{array}$ & $\begin{array}{l}-0.139 \\
(0.538)\end{array}$ \\
\hline Industry & Yes & Yes & No & No \\
\hline Purpose & Yes & Yes & No & No \\
\hline Lead Agent & Yes & Yes & No & No \\
\hline $\begin{array}{l}\text { Observations } \\
R^{2}\end{array}$ & $\begin{array}{c}6192 \\
0.024\end{array}$ & $\begin{array}{l}1745 \\
0.087\end{array}$ & 6255 & 6251 \\
\hline Pseudo $R^{2}$ & & & 0.028 & 0.038 \\
\hline
\end{tabular}

Note: This table shows the effect of the change in the broad dollar index on the amount flex. The change in the broad dollar index is calculated as the change from launch date to launch date plus 12 days, which is the average length of origination in our sample. The dependent variable is the weighted amount flex, calculated as the amount flex divided by the talk amount. Column 1 includes all loans, treating loans without an amount flex as having zero flex. Column 2 then restricts the sample to only loans that have an Amount Flex. Column 3 and Column 4 run a logit regression on all loans, where the dependent variable is a dummy variable that indicates whether the loan amount was adjusted upward or downward, respectively. All loan controls are taken from LCD and are described in Appendix A. The sample period is from 2009 to 2019. Robust standard errors are in parentheses. *, **, and ${ }^{* * *}$ denote significance at the $10 \%, 5 \%$, and $1 \%$ level. 
Table 9: Primary Market Participants' Rents

\begin{tabular}{|c|c|c|c|}
\hline & $\begin{array}{c}(1) \\
\text { Launch to Break }\end{array}$ & $\begin{array}{c}(2) \\
\text { Launch to Flex } \\
\end{array}$ & $\begin{array}{c}(3) \\
\text { Flex to Break }\end{array}$ \\
\hline$\Delta$ Broad Dollar (Launch to Break) & $\begin{array}{c}-0.0233^{* * *} \\
(0.00727)\end{array}$ & & \\
\hline$\Delta$ Broad Dollar (Launch to Flex) & & $\begin{array}{l}-0.0140^{*} \\
(0.00763)\end{array}$ & \\
\hline$\Delta$ Broad Dollar (Flex to Break) & & & $\begin{array}{c}-0.0294 * * \\
(0.0141)\end{array}$ \\
\hline Talk Amount(log) & $\begin{array}{c}0.00479 \\
(0.00699)\end{array}$ & $\begin{array}{c}0.00426 \\
(0.00700)\end{array}$ & $\begin{array}{c}0.00538 \\
(0.00709)\end{array}$ \\
\hline Talk Spread (log) & $\begin{array}{l}0.602^{* * *} \\
(0.0314)\end{array}$ & $\begin{array}{l}0.596^{* * *} \\
(0.0312)\end{array}$ & $\begin{array}{c}0.606^{* * *} \\
(0.0312)\end{array}$ \\
\hline Years to Maturity (log) & $\begin{array}{c}0.0470 \\
(0.0287)\end{array}$ & $\begin{array}{l}0.0479^{*} \\
(0.0289)\end{array}$ & $\begin{array}{c}0.0379 \\
(0.0291)\end{array}$ \\
\hline Sponsored & $\begin{array}{c}-0.0743^{* * *} \\
(0.0143)\end{array}$ & $\begin{array}{c}-0.0747^{* * *} \\
(0.0142)\end{array}$ & $\begin{array}{c}-0.0755^{* * *} \\
(0.0144)\end{array}$ \\
\hline Rated & $\begin{array}{c}0.0154 \\
(0.0264)\end{array}$ & $\begin{array}{c}0.0151 \\
(0.0265)\end{array}$ & $\begin{array}{c}0.0211 \\
(0.0268)\end{array}$ \\
\hline Cov-Lite & $\begin{array}{c}-0.0573^{* * *} \\
(0.0129)\end{array}$ & $\begin{array}{c}-0.0570^{* * *} \\
(0.0129)\end{array}$ & $\begin{array}{c}-0.0590^{* * *} \\
(0.0130)\end{array}$ \\
\hline Middle Market & $\begin{array}{c}-0.0926^{* * *} \\
(0.0213)\end{array}$ & $\begin{array}{c}-0.0933^{* * *} \\
(0.0211)\end{array}$ & $\begin{array}{c}-0.1000^{* * *} \\
(0.0216)\end{array}$ \\
\hline$\Delta$ VIX (log) & $\begin{array}{c}-0.0894 * * * \\
(0.0336)\end{array}$ & $\begin{array}{l}-0.0578^{*} \\
(0.0341)\end{array}$ & $\begin{array}{l}-0.0128 \\
(0.0541)\end{array}$ \\
\hline$\Delta$ US Corp AAA-BBB Spread & $\begin{array}{c}-0.550 * * * \\
(0.126)\end{array}$ & $\begin{array}{c}-0.782^{* * *} \\
(0.154)\end{array}$ & $\begin{array}{l}-0.230 \\
(0.222)\end{array}$ \\
\hline$\Delta$ US Term Spread & $\begin{array}{l}-0.0850 \\
(0.0677)\end{array}$ & $\begin{array}{r}-0.165^{* *} \\
(0.0722)\end{array}$ & $\begin{array}{c}0.162 \\
(0.134)\end{array}$ \\
\hline$\Delta$ Economic Conditions Index & $\begin{array}{l}0.0901^{* *} \\
(0.0441)\end{array}$ & $\begin{array}{l}0.0810^{*} \\
(0.0489)\end{array}$ & $\begin{array}{l}0.0498 \\
(0.114)\end{array}$ \\
\hline$\Delta$ US Libor & $\begin{array}{l}0.0515 \\
(0.183)\end{array}$ & $\begin{array}{l}0.0184 \\
(0.196)\end{array}$ & $\begin{array}{c}0.131 \\
(0.455)\end{array}$ \\
\hline$\Delta 2$-Year Treasury & $\begin{array}{c}0.396^{* * *} \\
(0.100)\end{array}$ & $\begin{array}{c}0.235^{* *} \\
(0.106)\end{array}$ & $\begin{array}{c}0.600^{* * *} \\
(0.178)\end{array}$ \\
\hline Industry & Yes & Yes & Yes \\
\hline Purpose & Yes & Yes & Yes \\
\hline Lead Agent & Yes & Yes & Yes \\
\hline Observations & 5015 & 5015 & 5015 \\
\hline$R^{2}$ & 0.257 & 0.253 & 0.235 \\
\hline
\end{tabular}

Note: This table shows the effect of various broad dollar index changes on the underpricing variable. The dependent variable is a measure of underpricing, calculated as the break price minus the final OID. This table includes all loans regardless of flex date, but includes only loans with a break price. In cases where there was no final OID, the OID was assumed to be 1. The three changes are broad dollar change from launch date to flex date; launch date to break date; and flex date to break date. All loan controls are taken from LCD and described in Appendix A. The sample period is from 2009 to 2019. Robust standard errors are in parentheses. $*, * *$, and $* * *$ denote significance at the $10 \%, 5 \%$, and $1 \%$ level. 
Table 10: Appreciations vs. Depreciations

\begin{tabular}{|c|c|c|c|c|c|}
\hline & $\begin{array}{c}(1) \\
\text { Effective Spread Flex }\end{array}$ & $\begin{array}{c}(2) \\
\text { OID Flex }\end{array}$ & $\begin{array}{c}(3) \\
\text { Spread Flex }\end{array}$ & $\begin{array}{c}(4) \\
\text { Amount Flex }\end{array}$ & $\begin{array}{c}(5) \\
\text { Underpricing } \\
\end{array}$ \\
\hline$\Delta$ Broad Dollar $>0$ (Launch to Flex $)$ & $\begin{array}{c}15.87^{* * *} \\
(2.563)\end{array}$ & $\begin{array}{c}4.468^{* * *} \\
(1.638)\end{array}$ & $\begin{array}{c}14.76^{* * *} \\
(2.364)\end{array}$ & $\begin{array}{c}-0.0221^{* * *} \\
(0.00841)\end{array}$ & $\begin{array}{c}-0.0659^{* * *} \\
(0.0211)\end{array}$ \\
\hline$\Delta$ Broad Dollar $<0$ (Launch to Flex $)$ & $\begin{array}{l}-4.503 \\
(2.931)\end{array}$ & $\begin{array}{c}-2.550 \\
(1.863)\end{array}$ & $\begin{array}{l}-3.866 \\
(2.713)\end{array}$ & $\begin{array}{r}-0.00136 \\
(0.0116)\end{array}$ & $\begin{array}{c}0.0231 \\
(0.0236)\end{array}$ \\
\hline$\Delta$ Broad Dollar 0 & $\begin{array}{c}1.593 \\
(4.879)\end{array}$ & $\begin{array}{c}0.284 \\
(2.323)\end{array}$ & $\begin{array}{c}1.522 \\
(4.517)\end{array}$ & $\begin{array}{c}0.0137 \\
(0.0221)\end{array}$ & $\begin{array}{l}-0.0549 \\
(0.0530)\end{array}$ \\
\hline Talk Amount(log) & $\begin{array}{c}1.261 \\
(1.019)\end{array}$ & $\begin{array}{c}1.874^{* * *} \\
(0.539)\end{array}$ & $\begin{array}{c}0.792 \\
(0.944)\end{array}$ & $\begin{array}{c}-0.0255^{* * *} \\
(0.00601)\end{array}$ & $\begin{array}{l}0.0203^{* *} \\
(0.00994)\end{array}$ \\
\hline Talk Spread (log) & $\begin{array}{c}21.74^{* * * *} \\
(4.538)\end{array}$ & $\begin{array}{c}24.31^{* * *} \\
(3.059)\end{array}$ & $\begin{array}{c}15.67^{* * *} \\
(4.147)\end{array}$ & $\begin{array}{c}-0.0368^{*} \\
(0.0188)\end{array}$ & $\begin{array}{c}0.673^{* * *} * \\
(0.0454)\end{array}$ \\
\hline Years to Maturity (log) & $\begin{array}{c}-14.47^{* * *} \\
(4.786)\end{array}$ & $\begin{array}{l}-4.713^{*} \\
(2.578)\end{array}$ & $\begin{array}{c}-13.30^{* * *} \\
(4.463)\end{array}$ & $\begin{array}{c}0.0217 \\
(0.0214)\end{array}$ & $\begin{array}{l}0.0830^{*} \\
(0.0462)\end{array}$ \\
\hline Sponsored & $\begin{array}{c}4.721^{* *} \\
(2.225)\end{array}$ & $\begin{array}{l}-1.030 \\
(1.161)\end{array}$ & $\begin{array}{c}4.979^{* *} \\
(2.081)\end{array}$ & $\begin{array}{c}-0.0238^{* *} \\
(0.00990)\end{array}$ & $\begin{array}{c}-0.0713^{* * *} \\
(0.0196)\end{array}$ \\
\hline Rated & $\begin{array}{l}-1.200 \\
(4.525)\end{array}$ & $\begin{array}{c}1.021 \\
(2.131)\end{array}$ & $\begin{array}{l}-1.455 \\
(4.261)\end{array}$ & $\begin{array}{r}-0.000295 \\
(0.00935)\end{array}$ & $\begin{array}{l}-0.0235 \\
(0.0394)\end{array}$ \\
\hline Cov-Lite & $\begin{array}{c}-5.096^{* *} \\
(2.099)\end{array}$ & $\begin{array}{l}-0.319 \\
(1.267)\end{array}$ & $\begin{array}{c}-5.016^{* * *} \\
(1.938)\end{array}$ & $\begin{array}{l}0.0225^{* *} \\
(0.00988)\end{array}$ & $\begin{array}{c}-0.0499^{* * *} \\
(0.0177)\end{array}$ \\
\hline Middle Market & $\begin{array}{c}18.22^{* * *} \\
(3.881)\end{array}$ & $\begin{array}{l}4.279^{* *} \\
(2.144)\end{array}$ & $\begin{array}{c}17.15^{* * *} \\
(3.634)\end{array}$ & $\begin{array}{c}-0.0314^{* * *} \\
(0.00807)\end{array}$ & $\begin{array}{c}-0.121^{* * *} \\
(0.0276)\end{array}$ \\
\hline$\Delta$ VIX $(\log )$ & $\begin{array}{c}-19.12^{* * *} \\
(5.681)\end{array}$ & $\begin{array}{l}-6.894 \\
(4.423)\end{array}$ & $\begin{array}{c}-17.40^{* * *} \\
(5.235)\end{array}$ & $\begin{array}{c}0.0272 \\
(0.0223)\end{array}$ & $\begin{array}{c}-0.128^{* * *} \\
(0.0468)\end{array}$ \\
\hline$\Delta$ US Corp AAA-BBB Spread & $\begin{array}{c}87.54^{* * *} \\
(24.75)\end{array}$ & $\begin{array}{c}51.12^{* * *} \\
(18.24)\end{array}$ & $\begin{array}{c}74.76^{* * *} \\
(22.49)\end{array}$ & $\begin{array}{l}-0.0741 \\
(0.0666)\end{array}$ & $\begin{array}{c}-0.752^{* * *} \\
(0.182)\end{array}$ \\
\hline$\Delta$ US Term Spread & $\begin{array}{c}9.949 \\
(12.16)\end{array}$ & $\begin{array}{l}-4.944 \\
(6.782)\end{array}$ & $\begin{array}{c}11.19 \\
(11.37)\end{array}$ & $\begin{array}{l}-0.0215 \\
(0.0387)\end{array}$ & $\begin{array}{c}-0.143 \\
(0.0929)\end{array}$ \\
\hline$\Delta$ Economic Conditions Index & $\begin{array}{l}-8.290 \\
(9.664)\end{array}$ & $\begin{array}{l}-1.750 \\
(5.456)\end{array}$ & $\begin{array}{l}-7.852 \\
(9.046)\end{array}$ & $\begin{array}{r}-0.00611 \\
(0.0255)\end{array}$ & $\begin{array}{c}0.0211 \\
(0.0653)\end{array}$ \\
\hline$\Delta$ US Libor & $\begin{array}{c}47.05 \\
(30.12)\end{array}$ & $\begin{array}{c}36.54 \\
(23.00)\end{array}$ & $\begin{array}{c}37.91 \\
(27.66)\end{array}$ & $\begin{array}{l}0.00996 \\
(0.0955)\end{array}$ & $\begin{array}{c}0.365 \\
(0.267)\end{array}$ \\
\hline$\Delta$ 2-Year Treasury & $\begin{array}{c}-39.91^{* *} \\
(16.54)\end{array}$ & $\begin{array}{l}-14.62 \\
(11.84)\end{array}$ & $\begin{array}{c}-36.25^{* *} \\
(15.25)\end{array}$ & $\begin{array}{c}0.0948 \\
(0.0672)\end{array}$ & $\begin{array}{l}0.0493 \\
(0.131)\end{array}$ \\
\hline Industry & Yes & Yes & Yes & Yes & Yes \\
\hline Purpose & Yes & Yes & Yes & Yes & Yes \\
\hline Lead Agent & Yes & Yes & Yes & Yes & Yes \\
\hline Observations & 2956 & 2956 & 2956 & 2956 & 2627 \\
\hline$R^{2}$ & 0.132 & 0.103 & 0.127 & 0.067 & 0.253 \\
\hline
\end{tabular}

Note: This table shows the effect of dollar appreciation and dollar depreciation separately on various flex variables. The effective spread flex is in basis points, calculated as the spread flex plus OID Flex divided by four. This table includes only loans that have a flex date. The change in the broad dollar index is calculated as the change from launch date to flex date. All loan controls are taken from LCD and are described in Appendix A. The sample period is from 2009 to 2019 . Robust standard errors are in parentheses. *, ${ }^{* *}$, and *** denote significance at the $10 \%, 5 \%$, and $1 \%$ level. 
Table 11: The Dollar, CIP deviations, and the Treasury Basis

\begin{tabular}{|c|c|c|c|c|c|c|}
\hline & $\overline{(1)}$ & $(2)$ & $(3)$ & (4) & 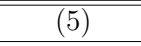 & 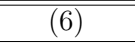 \\
\hline$\Delta$ Broad Dollar & $\begin{array}{c}5.589 * * * \\
(1.318)\end{array}$ & $\begin{array}{c}4.054^{* * *} \\
(1.259)\end{array}$ & $\begin{array}{c}5.971^{* * *} \\
(1.306)\end{array}$ & $\begin{array}{c}4.457^{* * *} \\
(1.266)\end{array}$ & $\begin{array}{c}4.475^{* * *} \\
(1.371)\end{array}$ & $\begin{array}{c}3.122^{* *} \\
(1.432)\end{array}$ \\
\hline$\Delta$ Broad CIP & & $\begin{array}{c}-2.124^{* *} \\
(0.864)\end{array}$ & & $\begin{array}{c}-2.980^{* * *} \\
(0.924)\end{array}$ & $\begin{array}{c}-2.292^{* *} \\
(0.974)\end{array}$ & $\begin{array}{c}-1.889^{*} \\
(1.014)\end{array}$ \\
\hline$\Delta$ 1-Year Treasury Basis & & & $\begin{array}{l}-0.221 \\
(0.230)\end{array}$ & $\begin{array}{c}-0.591^{* *} \\
(0.244)\end{array}$ & $\begin{array}{c}-0.653^{* * *} \\
(0.236)\end{array}$ & $\begin{array}{c}-0.499^{* *} \\
(0.238)\end{array}$ \\
\hline Talk Amount(log) & $\begin{array}{c}1.058 \\
(1.194)\end{array}$ & $\begin{array}{c}1.106 \\
(1.195)\end{array}$ & $\begin{array}{c}1.051 \\
(1.193)\end{array}$ & $\begin{array}{c}1.106 \\
(1.194)\end{array}$ & $\begin{array}{c}1.053 \\
(1.189)\end{array}$ & $\begin{array}{c}1.056 \\
(1.186)\end{array}$ \\
\hline Talk Spread (log) & $\begin{array}{c}27.26^{* * *} \\
(5.393)\end{array}$ & $\begin{array}{c}27.27^{* * * *} \\
(5.384)\end{array}$ & $\begin{array}{c}27.13^{* * *} \\
(5.393)\end{array}$ & $\begin{array}{c}26.94^{* * *} \\
(5.383)\end{array}$ & $\begin{array}{c}29.45^{* * *} \\
(5.441)\end{array}$ & $\begin{array}{c}27.33^{\text {**** }} \\
(5.563)\end{array}$ \\
\hline Years to Maturity (log) & $\begin{array}{c}-15.86^{* *} \\
(6.266)\end{array}$ & $\begin{array}{c}-15.66^{* *} \\
(6.337)\end{array}$ & $\begin{array}{c}-15.80^{* *} \\
(6.243)\end{array}$ & $\begin{array}{c}-15.42^{* *} \\
(6.304)\end{array}$ & $\begin{array}{c}-16.53^{* * *} \\
(6.411)\end{array}$ & $\begin{array}{c}-17.79^{* * * *} \\
(6.520)\end{array}$ \\
\hline Sponsored & $\begin{array}{c}3.604 \\
(2.596)\end{array}$ & $\begin{array}{c}3.742 \\
(2.592)\end{array}$ & $\begin{array}{c}3.621 \\
(2.597)\end{array}$ & $\begin{array}{c}3.841 \\
(2.591)\end{array}$ & $\begin{array}{c}3.693 \\
(2.581)\end{array}$ & $\begin{array}{c}5.603^{* *} \\
(2.567)\end{array}$ \\
\hline Rated & $\begin{array}{c}3.405 \\
(5.036)\end{array}$ & $\begin{array}{c}4.127 \\
(5.035)\end{array}$ & $\begin{array}{c}3.351 \\
(5.030)\end{array}$ & $\begin{array}{c}4.275 \\
(5.021)\end{array}$ & $\begin{array}{c}3.978 \\
(5.027)\end{array}$ & $\begin{array}{c}1.381 \\
(5.004)\end{array}$ \\
\hline Cov-Lite & $\begin{array}{c}-7.978^{* * *} \\
(2.246)\end{array}$ & $\begin{array}{c}-7.829 * * * \\
(2.241)\end{array}$ & $\begin{array}{c}-7.990^{* * *} \\
(2.247)\end{array}$ & $\begin{array}{c}-7.800^{* * *} \\
(2.239)\end{array}$ & $\begin{array}{c}-7.883^{* * *} \\
(2.230)\end{array}$ & $\begin{array}{c}-9.764^{* * *} \\
(2.378)\end{array}$ \\
\hline Middle Market & $\begin{array}{c}20.09^{* * *} \\
(3.921)\end{array}$ & $\begin{array}{c}20.20^{* * *} \\
(3.922)\end{array}$ & $\begin{array}{c}20.13^{* * *} \\
(3.918)\end{array}$ & $\begin{array}{c}20.33^{* * *} \\
(3.911)\end{array}$ & $\begin{array}{c}20.26^{* * *} \\
(3.894)\end{array}$ & $\begin{array}{c}19.45^{* * *} \\
(3.966)\end{array}$ \\
\hline$\Delta$ VIX $(\log )$ & & & & & $\begin{array}{c}-23.85^{* * *} \\
(6.037)\end{array}$ & $\begin{array}{c}-21.44^{* * * *} \\
(6.051)\end{array}$ \\
\hline$\Delta$ US Corp AAA-BBB Spread & & & & & $\begin{array}{c}74.07 * * * \\
(21.65)\end{array}$ & $\begin{array}{c}47.54^{* *} \\
(22.79)\end{array}$ \\
\hline$\Delta$ US Term Spread & & & & & $\begin{array}{c}7.379 \\
(11.98)\end{array}$ & $\begin{array}{c}3.652 \\
(12.79)\end{array}$ \\
\hline$\Delta$ Economic Conditions Index & & & & & $\begin{array}{c}-17.18^{*} \\
(9.776)\end{array}$ & $\begin{array}{c}-3.242 \\
(10.26)\end{array}$ \\
\hline$\Delta$ US Libor & & & & & $\begin{array}{c}81.60^{* *} \\
(35.63)\end{array}$ & $\begin{array}{c}41.19 \\
(47.50)\end{array}$ \\
\hline$\Delta$ 2-Year Treasury & & & & & $\begin{array}{c}-22.65 \\
(19.17)\end{array}$ & $\begin{array}{l}-4.540 \\
(19.10)\end{array}$ \\
\hline Constant & $\begin{array}{c}-143.5^{* * *} \\
(35.24)\end{array}$ & $\begin{array}{c}-145.0^{* * * *} \\
(35.22)\end{array}$ & $\begin{array}{c}-142.8^{\text {*** }} \\
(35.24)\end{array}$ & $\begin{array}{c}-143.6^{* * *} \\
(35.16)\end{array}$ & $\begin{array}{c}-155.9^{* * *} \\
(35.51)\end{array}$ & $\begin{array}{c}-138.9^{* * * *} \\
(36.00)\end{array}$ \\
\hline Industry & Yes & Yes & Yes & Yes & Yes & Yes \\
\hline Purpose & Yes & Yes & Yes & Yes & Yes & Yes \\
\hline Lead Agent & Yes & Yes & Yes & Yes & Yes & Yes \\
\hline Year-Quarter & No & No & No & No & No & Yes \\
\hline Observations & 2799 & 2799 & 2799 & 2799 & 2799 & 2799 \\
\hline$R^{2}$ & 0.125 & 0.129 & 0.126 & 0.131 & 0.146 & 0.196 \\
\hline
\end{tabular}

Note: This table shows the effect of the change in the broad dollar index on the effective spread flex when the regression controls for changes in CIP deviations and changes in safe asset demand. Changes in CIP deviations are computed as changes in the five-year dollar Libor cross-currency basis against G10 currencies from Avdjiev et al. (2019). Changes in safe asset demand are proxied by changes in the 1-year treasury basis from $\mathrm{Du}, \mathrm{Im}$, and Schreger (2018). The effective spread flex is in basis points, calculated as the spread flex plus OID Flex divided by four. This tagble includes only loans that have a flex date. The change in the broad dollar index is calculated as the change from launch date to flex date. All loan controls are taken from LCD and are described in Appendix A. The sample period is from 2009 to 2019 . Robust standard errors are in parentheses. ${ }^{*}, * *$, and ${ }^{* * *}$ denote significance at the $10 \%, 5 \%$, and $1 \%$ level. 


\section{Internet Appendix}

\section{A Data}

The appendix provides the definitions of all variables used in the empirical analysis and presents additional data summary statistics.

Table A1 gives detailed variables definitions and sources for each variable used in our analysis.

Figure A1 shows the ratings distribution of the loans in our sample.

Figure A2 shows the time series of the changes in the dollar and changes in US high-yield spreads. 


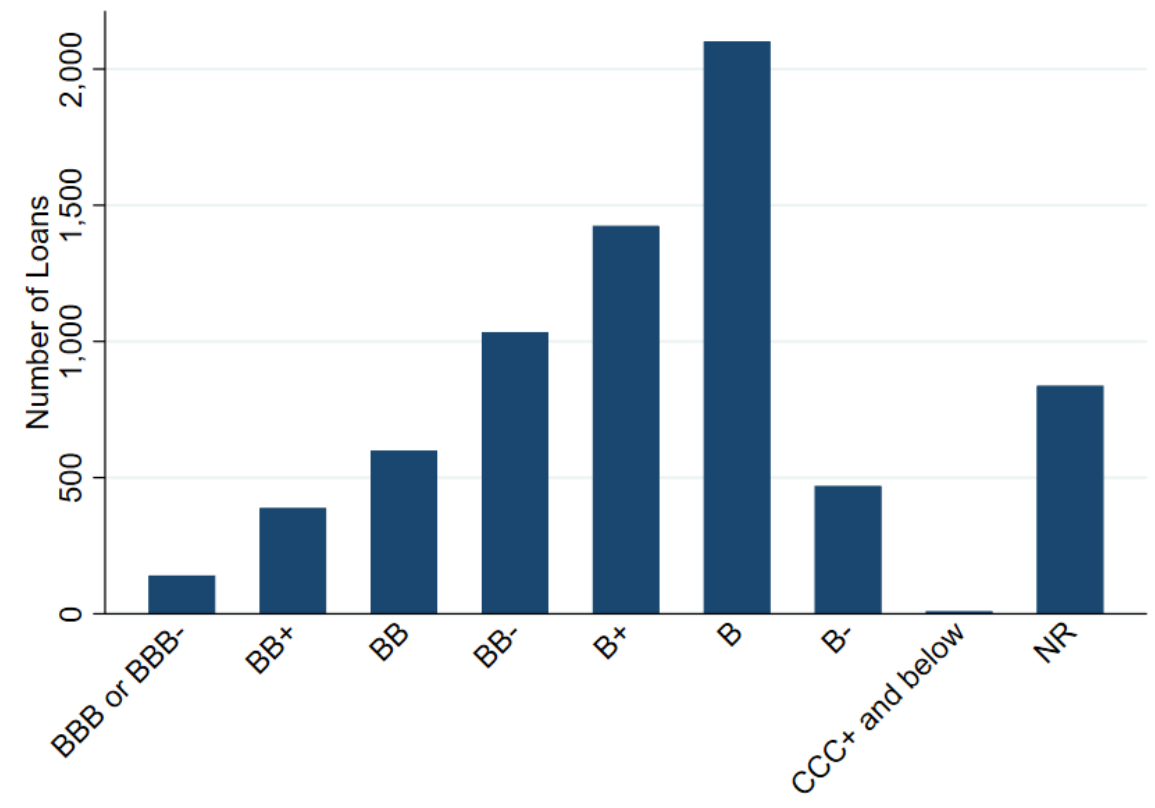

Figure A1: Loan Rating Distribution

Note: This figure shows the total number of loans for each ratings bucket in the sample 2009 to 2019. Sources: S\&P Capital IQ Leveraged Loan Commentary Data (LCD) and Dealscan. 


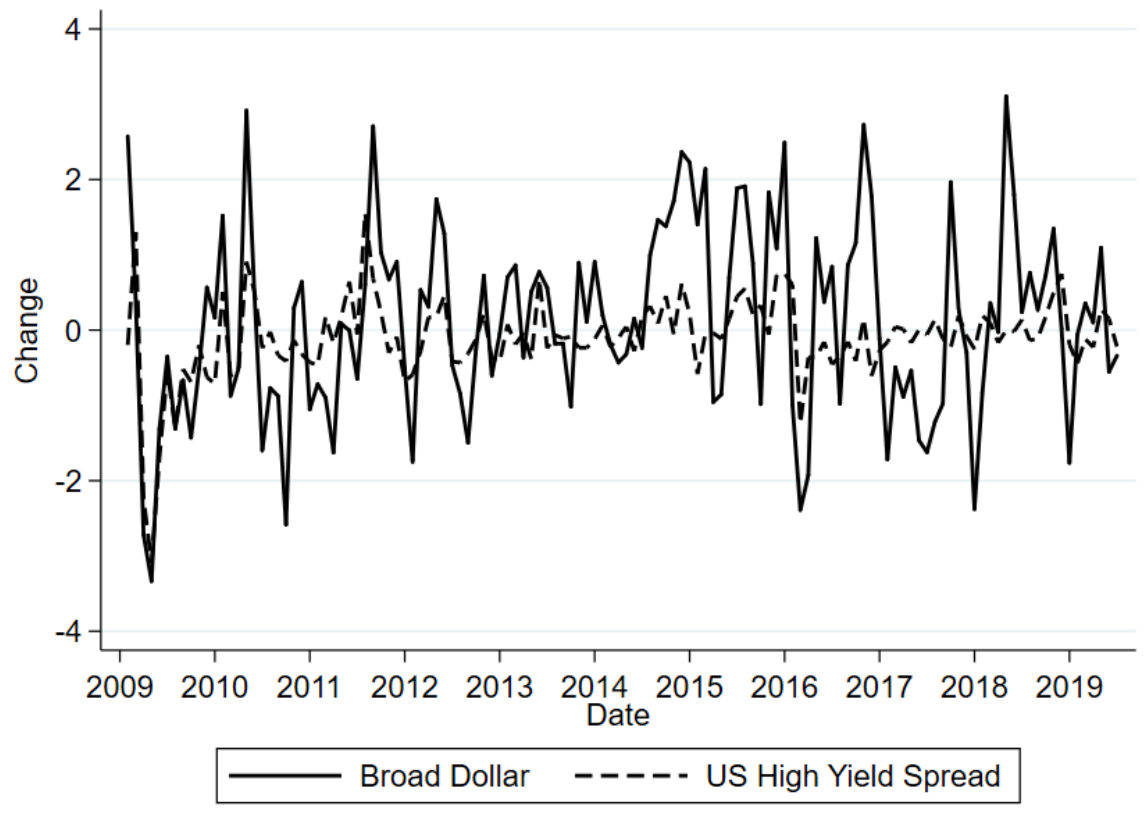

Figure A2: Changes in High Yield and Dollar Indexes

Note: This figure shows the change in broad dollar index and US high yield spread from 2009 to 2019. The correlation coefficient is 0.5. The high yield spread is the Master II Option-Adjusted Spread from FRED. 


\section{Table A1: Variable Description}

\begin{tabular}{|c|c|c|}
\hline Variable Name & Description & Source \\
\hline Break Date & Date the loan began trading in the secondary & \multirow{18}{*}{$\mathrm{S} \& \mathrm{P}$ LCD } \\
\hline Break Price & Price at secondary market in basis points & \\
\hline Effective Spread Flex & Equal to Spread Flex plus OID Flex divided by four & \\
\hline Flex Date & Date flex occurred & \\
\hline Industry & A categorical variable indicating the industry of the borrower & \\
\hline Issuer Name & Name of borrower & \\
\hline Launch Date & Date the deal came to market & \\
\hline Lead Agent & The administrative agent on the deal & \\
\hline Maturity & Length of loan in years & \\
\hline Middle Market & $\begin{array}{l}\text { A binary variable indicating whether the issuer is a middle } \\
\text { market borrower }\end{array}$ & \\
\hline OID Flex & $\begin{array}{l}\text { The amount in basis points that the OID has changed since } \\
\text { talk }\end{array}$ & \\
\hline Purpose & A categorical variable indicating the purpose of the loan & \\
\hline Rating & Company rating determined by Standard and Poor & \\
\hline Sponsored & A binary variable indicating whether the deal is sponsored & \\
\hline Spread Flex & $\begin{array}{l}\text { The amount in basis points that the spread has changed since } \\
\text { talk }\end{array}$ & \\
\hline Talk Amount & Initial deal size discussed, in millions USD & \\
\hline Talk Spread & Initial spread discussed & \\
\hline Underpricing & $\begin{array}{l}\text { Equal to the Break Price minus the final OID (or minus } 1 \\
\text { when OID is not given) }\end{array}$ & \\
\hline Company & Name of borrower & \multirow{3}{*}{ LSTA } \\
\hline Country & Country of borrower & \\
\hline Leveraged Loan Index & Market-weighted index tracking leveraged loans & \\
\hline Broad Dollar Index & Trade-weighted dollar indices & \multirow{7}{*}{$\begin{array}{l}\text { Federal Reserve } \\
\text { Board }\end{array}$} \\
\hline US Corporate Spread & Difference between AAA and BBB effective yields & \\
\hline US High Yield Spread & Master II Option-Adjusted & \\
\hline US Term Spread & 10-Year Treasury Yield minus 2-Year Treasury Yield & \\
\hline US 2-Year Treasury Yield & Yield on US Treasury 2-Year Bonds & \\
\hline VIX & Volatility Index & \\
\hline U.S. Libor & 3-month U.S. Libor & \\
\hline Treasury Basis & 1-Year Treasury Basis & $\begin{array}{l}\text { Du, Im, and } \\
\text { Schreger (2018) }\end{array}$ \\
\hline Economic Conditions Index & Aruoba-Diebold-Scotti Business Conditions Index & $\begin{array}{l}\text { Aruoba, } \text { S.B., } \\
\text { Diebold, F.X. and } \\
\text { Scotti, C. (2009) }\end{array}$ \\
\hline Import Intensity & Constructed as imports/(production+imports- exports) & BEA, U.S. Census \\
\hline Export Intensity & Constructed as exports/(production+imports- exports) & Bureau \\
\hline T1 Capital Ratio & Tier1 capital ratio & \multirow{8}{*}{ FR Y-9c Data } \\
\hline Retail Deposit Ratio & $\begin{array}{l}\text { Total deposits minus wholesale deposits defined as } \\
\text { (brokered deposits+large time deposits+fed funds pur- } \\
\text { chased+repos+other borrowed money) divided by total as- } \\
\text { sets }\end{array}$ & \\
\hline Liquid Asset Ratio & $\begin{array}{l}\text { Sum of non-interest bearing balances, interest bearing bal- } \\
\text { ances, available-for-sale securities, and securities held to ma- } \\
\text { turity divided by total assets }\end{array}$ & \\
\hline Noninterest Inc. Ratio & Non-interest income divided by net interest income & \\
\hline LHS Share & $\begin{array}{l}\text { Share of loans held for sale in total loans and lease financing } \\
\text { receivables }\end{array}$ & \\
\hline Trading Rev. Share & $\begin{array}{l}\text { Absolute trading revenues divided by the sum of non-interest } \\
\text { income and interest income }\end{array}$ & \\
\hline Net Charge-off to Loans & Charge-offs plus recoveries divided by total loans & \\
\hline Foreign Bank & Dummy variable equal to 1 if lead agent has a foreign parent & \\
\hline
\end{tabular}




\section{B Robustness Tests}

\section{U.S. vs Non-U.S. Borrowers}

We now study whether the effect of movements in the dollar index differ for U.S. and non-U.S. corporate borrowers. Non-U.S. corporate borrowers' ability to repay U.S. dollar denominated loans may decrease if most of the revenues are in local currency, directly linking credit risk and dollar movements. ${ }^{46}$ That said, if the effects of dollar movements on borrowing cost for U.S. and non-U.S. corporations are similar, this would suggest that movements in the dollar index reflect changes in global risk appetite and the global demand for risky assets that are transmitted to borrowers through higher spreads.

Table B1 shows the results of estimating equation 2 separately for U.S. and non-U.S. borrowers. Comparing the results for U.S. corporations without and with macroeconomic controls (columns 1 and 2) to the corresponding results for non-U.S. corporations (columns 3 and 4) shows that the effects are sizable and statistically significant. The effects of dollar movements on spreads for non-U.S. corporations are somewhat larger than for U.S. corporations, potentially reflecting the fact that the loans are denominated in U.S. dollars exposing non-U.S. borrowers to exchange rate risk. However, the differences in the dollar coefficient between U.S. and non-U.S. borrowers are not statistically significant (columns 5 and 6).

\section{Explanatory power of key risk proxies when the dollar is omitted}

To clarify the explanatory power of key variables that proxy for risk and uncertainty, we exclude the dollar from the effective spread flex regression in table B2.

Columns 1 and 2 show the result of estimating our main specification with changes in the 1-Year Treasury basis over the syndication period as main explanatory variable. We find no effect of changes in the 1-Year Treasury basis on changes in the loan spread. We then explore the effect of changes in uncertainty, measured as changes in the VIX. Columns 3 and 4 show the results of estimating our main specification with the changes in the VIX over the syndication period as main explanatory variable. We find no effect of changes in the VIX on loan spread changes. Taken together, these result suggest that neither scarcity of dollar safe assets or uncertainty explain the effective spread flex per se.

Columns 5 and 6 show that the U.S. yield spread is significantly positively correlated with the effective spread flex when changes in the dollar index are omitted as control variable. The coefficient increases compared to the results in earlier tables with change in the dollar included, as one might have expected because

\footnotetext{
${ }^{46}$ It is common, however, that loan agreements mandate corporation hedge exchange rate risk, partially alleviating this concern.
} 
changes in the high yield spread and the dollar a highly correlated. Similarly, columns 7 and 8 indicate that changes in CIP deviations have a statistically significant effect on the effective spread flex when changes in the dollar are not controlled for. Omitting changes in the dollar increases the coefficient also in this case as expected. 
Table B1: U.S. vs Non-U.S. Borrowers

\begin{tabular}{|c|c|c|c|c|c|c|}
\hline & \multicolumn{2}{|c|}{ "U.S. Borrowers } & \multicolumn{2}{|c|}{ Non-U.S. Borrowers } & \multicolumn{2}{|c|}{ Both } \\
\hline & $\begin{array}{l}(1) \\
\mathrm{FE}\end{array}$ & $\begin{array}{c}(2) \\
\text { Macro Var }\end{array}$ & $\begin{array}{l}(3) \\
\text { FE }\end{array}$ & $\begin{array}{c}(4) \\
\text { Macro Var }\end{array}$ & $\begin{array}{l}(5) \\
\text { FE }\end{array}$ & $\begin{array}{c}(6) \\
\text { Macro Var }\end{array}$ \\
\hline$\Delta$ Broad Dollar (Launch to Flex) & $\begin{array}{c}6.381^{* * *} \\
(1.184)\end{array}$ & $\begin{array}{c}5.458^{* * *} * \\
(1.231)\end{array}$ & $\begin{array}{c}9.549 * * * \\
(2.815)\end{array}$ & $\begin{array}{c}8.902^{* * *} \\
(2.833)\end{array}$ & $\begin{array}{c}6.423^{* * *} \\
(1.184)\end{array}$ & $\begin{array}{c}5.560^{* * *} \\
(1.222)\end{array}$ \\
\hline Talk Amount(log) & $\begin{array}{c}0.804 \\
(1.065)\end{array}$ & $\begin{array}{c}0.869 \\
(1.059)\end{array}$ & $\begin{array}{c}-6.027^{*} \\
(3.184)\end{array}$ & $\begin{array}{c}-5.667^{*} \\
(3.168)\end{array}$ & $\begin{array}{l}-0.316 \\
(0.991)\end{array}$ & $\begin{array}{l}-0.222 \\
(0.986)\end{array}$ \\
\hline Talk Spread (log) & $\begin{array}{c}25.66^{* * *} \\
(4.803)\end{array}$ & $\begin{array}{c}28.08^{* * *} * \\
(4.828)\end{array}$ & $\begin{array}{c}26.20 \\
(16.06)\end{array}$ & $\begin{array}{c}26.52 \\
(17.22)\end{array}$ & $\begin{array}{c}26.13 * * * \\
(4.536)\end{array}$ & $\begin{array}{c}28.60^{* * * *} \\
(4.570)\end{array}$ \\
\hline Years to Maturity (log) & $\begin{array}{c}-16.89 * * * \\
(5.855)\end{array}$ & $\begin{array}{c}-17.23^{* * *} \\
(5.956)\end{array}$ & $\begin{array}{c}8.897 \\
(16.95)\end{array}$ & $\begin{array}{c}5.316 \\
(16.52)\end{array}$ & $\begin{array}{c}-12.64^{* *} \\
(5.437)\end{array}$ & $\begin{array}{c}-13.36^{* *} \\
(5.494)\end{array}$ \\
\hline Sponsored & $\begin{array}{c}2.550 \\
(2.362)\end{array}$ & $\begin{array}{c}2.465 \\
(2.348)\end{array}$ & $\begin{array}{l}-6.912 \\
(7.921)\end{array}$ & $\begin{array}{l}-7.829 \\
(7.814)\end{array}$ & $\begin{array}{c}2.043 \\
(2.230)\end{array}$ & $\begin{array}{c}1.831 \\
(2.212)\end{array}$ \\
\hline Rated & $\begin{array}{c}3.576 \\
(4.602)\end{array}$ & $\begin{array}{c}3.898 \\
(4.624)\end{array}$ & $\begin{array}{c}4.261 \\
(10.92)\end{array}$ & $\begin{array}{c}4.572 \\
(11.64)\end{array}$ & $\begin{array}{c}5.108 \\
(4.356)\end{array}$ & $\begin{array}{c}5.605 \\
(4.377)\end{array}$ \\
\hline Cov-Lite & $\begin{array}{c}-7.237^{* * *} * \\
(2.118)\end{array}$ & $\begin{array}{c}-7.075^{* * *} \\
(2.089)\end{array}$ & $\begin{array}{l}-8.553 \\
(6.616)\end{array}$ & $\begin{array}{l}-7.789 \\
(6.454)\end{array}$ & $\begin{array}{c}-7.440^{* * *} \\
(1.996)\end{array}$ & $\begin{array}{c}-7.121^{* * *} \\
(1.967)\end{array}$ \\
\hline Middle Market & $\begin{array}{c}17.42^{* * *} \\
(3.807)\end{array}$ & $\begin{array}{c}17.10^{* * *} \\
(3.791)\end{array}$ & $\begin{array}{c}10.52 \\
(14.09)\end{array}$ & $\begin{array}{l}13.18 \\
(14.91)\end{array}$ & $\begin{array}{c}16.12^{* * *} \\
(3.654)\end{array}$ & $\begin{array}{c}15.90^{* * * *} \\
(3.635)\end{array}$ \\
\hline$\Delta$ VIX $(\log )$ & & $\begin{array}{c}-21.73^{* * *} \\
(5.509)\end{array}$ & & $\begin{array}{l}-20.01 \\
(18.35)\end{array}$ & & $\begin{array}{c}-22.23^{* * *} \\
(5.237)\end{array}$ \\
\hline$\Delta$ US Corp AAA-BBB Spread & & $\begin{array}{c}88.38^{* * *} \\
(20.48)\end{array}$ & & $\begin{array}{c}85.30 \\
(73.29)\end{array}$ & & $\begin{array}{c}84.54^{* * *} \\
(17.93)\end{array}$ \\
\hline$\Delta$ US Term Spread & & $\begin{array}{c}12.54 \\
(11.50)\end{array}$ & & $\begin{array}{c}36.32 \\
(38.66)\end{array}$ & & $\begin{array}{c}13.30 \\
(10.95)\end{array}$ \\
\hline$\Delta$ Economic Conditions Index & & $\begin{array}{l}-12.91 \\
(9.345)\end{array}$ & & $\begin{array}{l}-12.21 \\
(35.31)\end{array}$ & & $\begin{array}{l}-11.31 \\
(9.075)\end{array}$ \\
\hline$\Delta$ US Libor & & $\begin{array}{l}54.98^{*} \\
(28.45)\end{array}$ & & $\begin{array}{l}-115.9 \\
(101.6)\end{array}$ & & $\begin{array}{l}50.69^{*} \\
(26.31)\end{array}$ \\
\hline$\Delta$ 2-Year Treasury & & $\begin{array}{l}-26.02 \\
(16.29)\end{array}$ & & $\begin{array}{l}-0.667 \\
(65.41)\end{array}$ & & $\begin{array}{l}-23.84 \\
(15.63)\end{array}$ \\
\hline$\Delta$ Dollar X Foreign Borrower & & & & & $\begin{array}{l}1.902 \\
(2.876)\end{array}$ & $\begin{array}{c}2.188 \\
(2.925)\end{array}$ \\
\hline Industry & Yes & Yes & Yes & Yes & Yes & Yes \\
\hline Purpose & Yes & Yes & Yes & Yes & Yes & Yes \\
\hline Lead Agent & Yes & Yes & Yes & Yes & Yes & Yes \\
\hline Observations & 3224 & 3224 & 391 & 391 & 3621 & 3621 \\
\hline$R^{2}$ & 0.116 & 0.134 & 0.282 & 0.298 & 0.112 & 0.129 \\
\hline
\end{tabular}

Note: This table tests whether the effect of dollar movements on the effective spread flex differs by borrower region. Column 1 and 2 are based on a sample with U.S. borrowers. Columns 3 and 4 only include non-U.S. borrowers. Regressions in columns 5 and 6 are based on a sample with both types of borrowers but include a dummy variable that takes the value of 1 for non-U.S. borrowers. The dependent variable is the effective spread flex in basis points, calculated as the spread flex plus OID flex divided by four. Only loans with flex dates are included. Control variables are described in Appendix A. The sample period is from 2009 to 2019 . Robust standard errors are in parentheses. ${ }^{*}, * *$, and ${ }^{* * *}$ denote significance at the $10 \%, 5 \%$, and $1 \%$ level. 
Table B2: Explanatory power of key risk and uncertainty proxies

\begin{tabular}{|c|c|c|c|c|c|c|c|c|}
\hline & (1) & $(2)$ & $(3)$ & (4) & (5) & (6) & (7) & (8) \\
\hline$\Delta$ 1-Year Treasury Basis & $\begin{array}{c}-0.149 \\
(0.181)\end{array}$ & $\begin{array}{c}-0.187 \\
(0.224)\end{array}$ & & & & & & \\
\hline$\Delta$ VIX $(\log )$ & & & $\begin{array}{c}-1.791 \\
(5.234)\end{array}$ & $\begin{array}{l}-1.696 \\
(5.353)\end{array}$ & & & & \\
\hline$\Delta$ US Corp AAA-BBB Spread & & & & & $\begin{array}{c}111.5^{* * *} \\
(14.50)\end{array}$ & $\begin{array}{c}115.1^{* * *} \\
(20.77)\end{array}$ & & \\
\hline$\Delta$ Broad CIP & & & & & & & $\begin{array}{c}-3.359^{* * * *} \\
(0.610)\end{array}$ & $\begin{array}{c}-3.061 \text { *** } \\
(0.861)\end{array}$ \\
\hline Talk Amoung (log) & & $\begin{array}{c}0.846 \\
(1.072)\end{array}$ & & $\begin{array}{c}0.844 \\
(1.070)\end{array}$ & & $\begin{array}{c}0.904 \\
(1.067)\end{array}$ & & $\begin{array}{c}0.929 \\
(1.073)\end{array}$ \\
\hline Talk Spread (log) & & $\begin{array}{c}25.89^{* * *} \\
(4.825)\end{array}$ & & $\begin{array}{c}25.98^{* * * *} \\
(4.823)\end{array}$ & & $\begin{array}{c}28.85^{* * *} \\
(4.788)\end{array}$ & & $\begin{array}{c}25.97^{* * * *} \\
(4.804)\end{array}$ \\
\hline Years to Maturity (log) & & $\begin{array}{c}-16.13^{* * *} \\
(5.748)\end{array}$ & & $\begin{array}{c}-16.16^{* * * *} \\
(5.769)\end{array}$ & & $\begin{array}{c}-16.18^{* * * *} \\
(5.834)\end{array}$ & & $\begin{array}{c}-16.02^{\text {*** }} \\
(5.890)\end{array}$ \\
\hline Sponsored & & $\begin{array}{c}2.650 \\
(2.378)\end{array}$ & & $\begin{array}{c}2.661 \\
(2.375)\end{array}$ & & $\begin{array}{c}2.169 \\
(2.344)\end{array}$ & & $\begin{array}{c}2.792 \\
(2.365)\end{array}$ \\
\hline Rated & & $\begin{array}{c}3.872 \\
(4.597)\end{array}$ & & $\begin{array}{c}3.914 \\
(4.600)\end{array}$ & & $\begin{array}{c}4.293 \\
(4.605)\end{array}$ & & $\begin{array}{c}4.808 \\
(4.598)\end{array}$ \\
\hline Cov-Lite & & $\begin{array}{c}-6.940^{* * *} \\
(2.140)\end{array}$ & & $\begin{array}{c}-6.915^{* * * *} \\
(2.141)\end{array}$ & & $\begin{array}{c}-6.763^{* * * *} \\
(2.103)\end{array}$ & & $\begin{array}{c}-6.821^{* * *} \\
(2.126)\end{array}$ \\
\hline Middle Market & & $\begin{array}{c}17.30^{* * *} \\
(3.830)\end{array}$ & & $\begin{array}{c}17.22 * * * \\
(3.833)\end{array}$ & & $\begin{array}{c}16.63^{* * *} \\
(3.810)\end{array}$ & & $\begin{array}{c}17.32^{* * * *} \\
(3.825)\end{array}$ \\
\hline Industry & No & Yes & No & Yes & No & Yes & No & Yes \\
\hline Purpose & No & Yes & No & Yes & No & Yes & No & Yes \\
\hline Lead Agent & No & Yes & No & Yes & No & Yes & No & Yes \\
\hline Observations & 3242 & 3224 & 3242 & 3224 & 3242 & 3224 & 3242 & 3224 \\
\hline $\begin{array}{l}R^{2} \\
\text { Pseudo } R^{2}\end{array}$ & 0.000 & 0.103 & 0.000 & 0.103 & 0.018 & 0.121 & 0.009 & 0.111 \\
\hline
\end{tabular}

Note: This table shows the effect of the Treasury basis, the VIX, CIP deviations, and the U.S. high yield spread on the effective spread flex for loans with flexes only. The changes in the dollar index are left out as control variable. All controls are described in Appendix A. The sample period is from 2009 to 2019 . Robust standard errors are in parentheses. *, $* *$, and ${ }^{* * *}$ denote significance at the $10 \%, 5 \%$, and $1 \%$ level. 
Table B3: Controlling for risk aversion and economic uncertainty from Bekaert, Engstrom, and Xu (2019)

\begin{tabular}{|c|c|c|c|c|c|c|}
\hline & (1) & $(2)$ & $(3)$ & (4) & $(5)$ & (6) \\
\hline$\Delta$ Broad Dollar & $\begin{array}{c}.314^{* * *} \\
(1.266)\end{array}$ & $\begin{array}{c}4.459^{* * *} \\
(1.363)\end{array}$ & $\begin{array}{c}2.684^{*} \\
(1.410)\end{array}$ & $\begin{array}{c}4.984^{* * *} \\
(1.304)\end{array}$ & $\begin{array}{c}5.752^{* * *} \\
(1.403)\end{array}$ & $\begin{array}{c}3.887^{* * * *} \\
(1.451)\end{array}$ \\
\hline$\Delta$ Broad CIP & $\begin{array}{c}-2.706^{* * *} \\
(0.945)\end{array}$ & $\begin{array}{c}-2.854^{* * *} \\
(0.947)\end{array}$ & $\begin{array}{c}-2.163^{* *} \\
(0.987)\end{array}$ & $\begin{array}{c}-3.115^{* * *} \\
(0.924)\end{array}$ & $\begin{array}{c}-2.979^{* * *} \\
(0.938)\end{array}$ & $\begin{array}{c}-2.328^{* *} \\
(0.975)\end{array}$ \\
\hline$\Delta 1$-Year Treasury Basis & $\begin{array}{c}-0.624^{* *} \\
(0.242)\end{array}$ & $\begin{array}{c}-0.713^{* * *} \\
(0.238)\end{array}$ & $\begin{array}{c}-0.530^{* *} \\
(0.239)\end{array}$ & $\begin{array}{c}-0.498^{* *} \\
(0.243)\end{array}$ & $\begin{array}{c}-0.594^{* *} \\
(0.238)\end{array}$ & $\begin{array}{c}-0.413^{*} \\
(0.238)\end{array}$ \\
\hline$\Delta$ Uncertainty Index & $\begin{array}{c}16.22 \\
(10.63)\end{array}$ & $\begin{array}{c}10.11 \\
(12.79)\end{array}$ & $\begin{array}{c}3.705 \\
(12.55)\end{array}$ & & & \\
\hline$\Delta$ Risk Aversion Index & & & & $\begin{array}{c}-11.75^{* *} \\
(4.810)\end{array}$ & $\begin{array}{c}-16.13^{* * *} \\
(4.992)\end{array}$ & $\begin{array}{c}-16.68^{* * *} \\
(4.972)\end{array}$ \\
\hline Talk Amount(log) & $\begin{array}{c}1.129 \\
(1.195)\end{array}$ & $\begin{array}{c}1.194 \\
(1.194)\end{array}$ & $\begin{array}{c}1.180 \\
(1.190)\end{array}$ & $\begin{array}{c}1.001 \\
(1.190)\end{array}$ & $\begin{array}{c}1.101 \\
(1.190)\end{array}$ & $\begin{array}{c}1.058 \\
(1.188)\end{array}$ \\
\hline Talk Spread (log) & $\begin{array}{c}27.22^{* * *} \\
(5.377)\end{array}$ & $\begin{array}{c}28.04^{* * *} \\
(5.435)\end{array}$ & $\begin{array}{c}26.38^{* * *} \\
(5.557)\end{array}$ & $\begin{array}{c}26.77^{* * *} \\
(5.383)\end{array}$ & $\begin{array}{c}27.64^{* * *} \\
(5.448)\end{array}$ & $\begin{array}{c}26.53^{* * *} \\
(5.565)\end{array}$ \\
\hline Years to Maturity (log) & $\begin{array}{c}-15.13^{* *} \\
(6.301)\end{array}$ & $\begin{array}{c}-16.19^{* *} \\
(6.355)\end{array}$ & $\begin{array}{c}-17.73^{* * *} \\
(6.485)\end{array}$ & $\begin{array}{c}-15.69^{* *} \\
(6.329)\end{array}$ & $\begin{array}{c}-16.86^{* * *} \\
(6.415)\end{array}$ & $\begin{array}{c}-18.11^{* * *} \\
(6.517)\end{array}$ \\
\hline Sponsored & $\begin{array}{c}3.924 \\
(2.588)\end{array}$ & $\begin{array}{c}4.032 \\
(2.586)\end{array}$ & $\begin{array}{c}5.790^{* *} \\
(2.568)\end{array}$ & $\begin{array}{c}3.856 \\
(2.595)\end{array}$ & $\begin{array}{c}4.050 \\
(2.594)\end{array}$ & $\begin{array}{c}5.750^{* *} \\
(2.572)\end{array}$ \\
\hline Rated & $\begin{array}{c}4.062 \\
(5.024)\end{array}$ & $\begin{array}{c}3.700 \\
(5.038)\end{array}$ & $\begin{array}{c}0.887 \\
(5.018)\end{array}$ & $\begin{array}{c}4.398 \\
(4.998)\end{array}$ & $\begin{array}{c}4.167 \\
(5.018)\end{array}$ & $\begin{array}{c}1.453 \\
(4.995)\end{array}$ \\
\hline Cov-Lite & $\begin{array}{c}-7.838^{* * *} \\
(2.236)\end{array}$ & $\begin{array}{c}-8.146^{* * *} \\
(2.249)\end{array}$ & $\begin{array}{c}-9.948^{* * *} \\
(2.386)\end{array}$ & $\begin{array}{c}-7.719^{* * *} \\
(2.238)\end{array}$ & $\begin{array}{c}-7.979^{* * *} \\
(2.242)\end{array}$ & $\begin{array}{c}-9.836^{* * *} \\
(2.381)\end{array}$ \\
\hline Middle Market & $\begin{array}{c}19.99 * * * \\
(3.897)\end{array}$ & $\begin{array}{c}20.82^{* * *} \\
(3.906)\end{array}$ & $\begin{array}{c}19.65^{* * *} \\
(3.963)\end{array}$ & $\begin{array}{c}20.49^{* * *} \\
(3.914)\end{array}$ & $\begin{array}{c}21.11^{* * *} \\
(3.910)\end{array}$ & $\begin{array}{c}19.76^{* * *} \\
(3.963)\end{array}$ \\
\hline$\Delta$ Economic Conditions Index & & $\begin{array}{c}-19.85^{* *} \\
(9.398)\end{array}$ & $\begin{array}{c}-3.224 \\
(10.04)\end{array}$ & & $\begin{array}{c}-19.25^{* *} \\
(9.376)\end{array}$ & $\begin{array}{c}-2.569 \\
(10.03)\end{array}$ \\
\hline$\Delta$ US Libor & & $\begin{array}{c}96.86^{* * *} \\
(35.14)\end{array}$ & $\begin{array}{c}55.80 \\
(46.95)\end{array}$ & & $\begin{array}{c}109.6^{* * *} \\
(34.79)\end{array}$ & $\begin{array}{c}64.63 \\
(47.04)\end{array}$ \\
\hline$\Delta 2$-Year Treasury & & $\begin{array}{l}-15.81 \\
(20.87)\end{array}$ & $\begin{array}{c}5.023 \\
(20.46)\end{array}$ & & $\begin{array}{c}-42.00^{* *} \\
(18.52)\end{array}$ & $\begin{array}{c}-16.92 \\
(17.98)\end{array}$ \\
\hline Constant & $\begin{array}{c}-145.7^{* * * *} \\
(35.15)\end{array}$ & $\begin{array}{c}-149.3^{* * * *} \\
(35.42)\end{array}$ & $\begin{array}{c}-134.0^{* * *} \\
(35.95)\end{array}$ & $\begin{array}{c}-141.7^{* * *} \\
(35.16)\end{array}$ & $\begin{array}{c}-145.6^{* * *} \\
(35.52)\end{array}$ & $\begin{array}{c}-133.9^{* * *} \\
(36.03)\end{array}$ \\
\hline Industry & Yes & Yes & Yes & Yes & Yes & Yes \\
\hline Purpose & Yes & Yes & Yes & Yes & Yes & Yes \\
\hline Lead Agent & Yes & Yes & Yes & Yes & Yes & Yes \\
\hline Year-Quarter & No & No & Yes & No & No & Yes \\
\hline Observations & 2799 & 2799 & 2799 & 2799 & 2799 & 2799 \\
\hline$R^{2}$ & 0.132 & 0.137 & 0.191 & 0.133 & 0.141 & 0.195 \\
\hline
\end{tabular}

Note: This table controls for risk aversion (columns 1 to 3 ) and uncertainty (columns4 to 6) indices from Bekaert, Engstrom, and Xu (2019). The dependent variable is the Effective Spread Flex in basis points, calculated as the Spread Flex plus OID Flex divided by four. Only loans with a flex date have been included. Robust standard errors are in parentheses. $*, * *$, and ${ }^{* * *}$ denote significance at the $10 \%, 5 \%$, and $1 \%$ level. 